\title{
Technology Deployment Annual Report 2009
}

December 2009

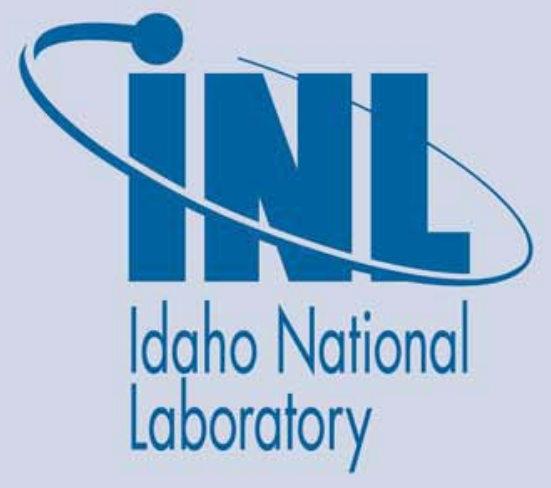

The INL is a U.S. Department of Energy National Laboratory operated by Battelle Energy Alliance 
INL/EXT-09-17434

\section{Technology Deployment Annual Report 2009}

December 2009

\section{Idaho National Laboratory \\ Idaho Falls, Idaho 83415}

http://www.inl.gov

Prepared for the

U.S. Department of Energy

Office of Nuclear Energy

Under DOE Idaho Operations Office

Contract DE-AC07-05ID14517 


\section{Technology Deployment}

Annual Report 2009

December 2009
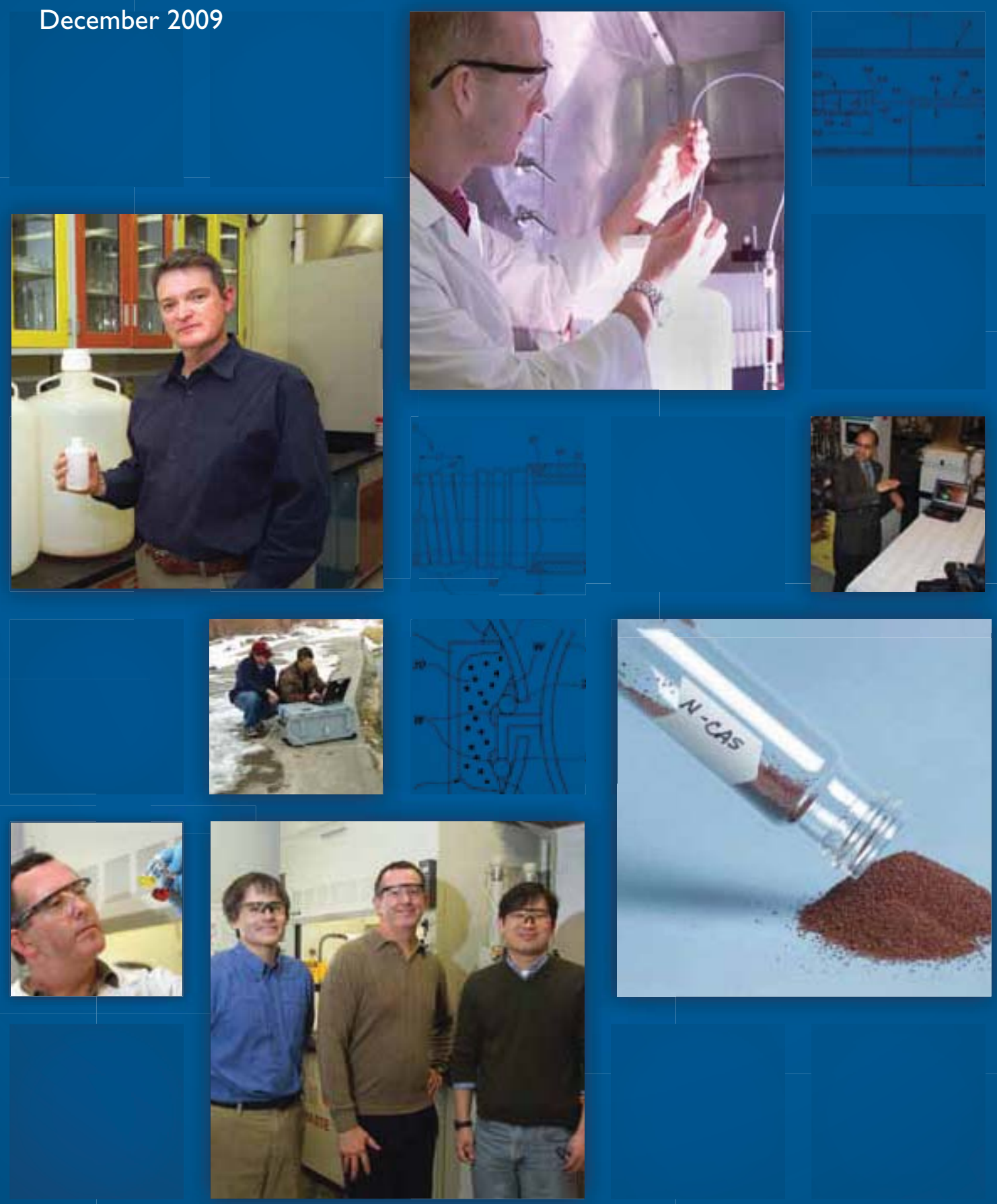

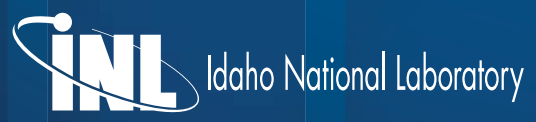




\section{Abstract}

Idaho National Laboratory (INL) is a Department of Energy (DOE) multi-program national laboratory that conducts research and development in all DOE mission areas. Like all other federal laboratories, INL has a statutory, technology transfer mission to make its capabilities and technologies available to all federal agencies, to state and local governments, and to universities and industry. To fulfill this mission, INL encourages its scientific, engineering, and technical staff to disclose new inventions and creations to ensure the resulting intellectual property is captured, protected, and made available to others who might benefit from it. Intellectual property is licensed to industrial partners for commercialization, creating jobs and delivering the benefits of federally funded technology to consumers. In other cases, unique capabilities are made available to other federal agencies or to regional small businesses to solve specific technical challenges. INL employees also work cooperatively with researchers and other technical staff of our partners to further develop emerging technologies.

This report is a catalog of selected Idaho National Laboratory technology transfer and commercialization transactions during fiscal year 2009. The size and diversity of INL technical resources, coupled with the large number of relationships with other organizations, virtually ensures that a report of this nature will fail to capture all interactions. Recognizing this limitation, this report focuses on transactions that are specifically authorized by technology transfer legislation (and corresponding contractual provisions) or involve the transfer of legal rights to technology to other parties.

This report was compiled from primary records, which were readily available to the INL's Office of Technology Deployment. However, the accomplishments cataloged in the report reflect the achievements and creativity of the researchers, technicians, support staff, and operators of the INL workforce.

\section{Disclaimer}

This information was prepared as an account of work sponsored by an agency of the U.S. Government. Neither the U.S. Government nor any agency thereof, nor any of their employees, makes any warranty, expressed or implied, or assumes any legal liability or responsibility for the accuracy, completeness, or usefulness, of any information, apparatus, product, or process disclosed, or represents that its use would not infringe privately owned rights. References herein to any specific commercial product, process, or service by trade name, trade mark, manufacturer, or otherwise, does not necessarily constitute or imply its endorsement, recommendation, or favoring by the U.S. Government or any agency thereof. The views and opinions of authors expressed herein do not necessarily state or reflect those of the U.S. Government or any agency thereof. 


\section{Contents}

From the Laboratory Director ...................................................................... 2

From the Technology Deployment Director...................................... 3

Intellectual Property................................................................................................ 4

Granted Copyrights ........................................................................... / 2

Royalties....................................................................................................... 13

License Agreements.................................................................................... 13

Cooperative Research and Development Agreements........... 16

Work For Others ................................................................................................ 18

Technical Assistance Program ........................................................................ 2 I

INL Economic Development 2009 Program Highlights............ 22

Leveraging Economic Development Partnerships........................ 22

Economic Development Education and Training............................ 23

INL Researchers Win 32009 R\&D I00 Awards...........................24

INL Technologies Recognized at Idaho Inovation Awards....... 24 


\section{From the Laboratory Director}

Tn America and around the world, this is a difficult economic time.

It is during these times that resilient institutions are challenged to respond with innovative research and technology development. Innovation, development and deployment ensure that nations remain successful and competitive in the world marketplace.

\section{"These significant achievements have created a record that instills pride in our talented people, our innovative research, and the exceptional productivity of our laboratory."}

\section{John Grossenbacher Director, Idaho National Laboratory}

In five years, Idaho National Laboratory has accumulated a highly successful record of deploying INL innovations, accomplishing important research and delivering competitive technologies. During this period, INL has attracted 267 projects representing more than $\$ 1.6$ billion in contracted work for others (programs other than DOE) and more than $\$ 164$ million through 103 Cooperative Research and Development Agreements (CRADAs). INL earned more than $\$ 5.8$ million in royalties from signing 453 license agreements, while generating 466 Invention Disclosure Records (IDR) and filing 277 patent applications. Nearly 200 patents have been issued to INL researchers during this time.

For fiscal year 2009, Technology Deployment reports another highly productive year in which INL professionals delivered nearly a quarter of a billion dollars of research and development work to customers in 48 contract agreements and 36 CRADAs. INL researchers earned three prestigious R\&D 100 Awards and a regional Idaho Innovation Award. Plus, these three technologies already have been commercialized through license agreements with private companies.

Also, this year our work has produced a record for royalties earned at more than $\$ 1.6$ million. The total number of licenses signed were 29, including 12 patent licenses and 17 copyright licenses. The number of IDRs submitted, which helps forecast future research successes, was 77 . We filed 36 patent applications and were issued 25 more patents.
As productive as INL researchers and staff have been, they made time for important contributions in the region by sharing their technical skills with community organizations and technology-based businesses. From various business education workshops and technical forums sponsored by INL, more than 200 regional community organizations and companies have advanced their entrepreneurial efforts to create successful technologies and new jobs in the region. We also delivered to 21

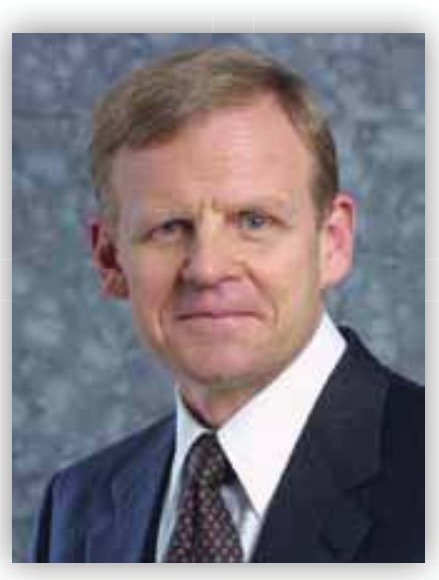
local communities and organizations technical assistance that was not otherwise available to them.

These statistical summaries tell part of the INL story, but a look at two award-winning achievements offers insight into the impressive impact our efforts deliver. Precision Nanoparticles enables production of uniform, prescribed sized nanoparticles with wide implications for many areas, especially for harvesting solar energy using copper indium disulfide in quantum dots. Also, the Water Sample Concentrator will for the first time permit safe, rapid collection of suspected contaminated water samples for transport to qualified laboratories for analysis. This technology enables quick response to natural disaster and homeland security emergencies.

These significant achievements have created a record that instills pride in our talented people, our innovative research, and the exceptional productivity of our laboratory. It demonstrates impact and contribution by INL professionals who are dedicated to working on important missions during the past five years.

Take some time to read about these significant achievements and be proud of our collective impact in the nation and region.

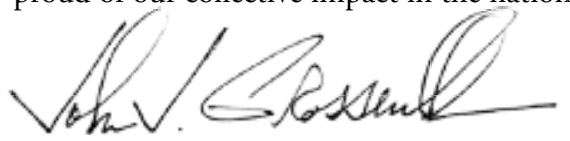

John Grossenbacher

Director, Idaho National Laboratory 


\section{From the Technology Deployment Director}

$\mathrm{T}$ he current global economic situation has exerted additional pressure on those in science and technology research to perform and deliver tangible benefits. As the new Secretary of Energy Steven Chu stated recently, "It's not about writing research papers anymore, you've got to deliver the goods."

\section{"This has been a year of fundamental change for Technology Deployment, complemented by significant positive performance. We continue to implement improvements in structure, performance, and compliance." \\ Brent Stacey \\ Director, Technology Deployment}

To make his point even more emphatically, Secretary Chu and his Department of Energy staff are increasing their support for technology transfer and taking actions to elevate its importance. Their actions include:

- Appointing a full time Technology Transfer Coordinator who will report directly to Secretary Chu and have a significant budget;

- Funding laboratory technology transfer projects through ARPA-E and Small Business technology transfer grants; and

- Establishing new laboratory management teams within DOE who are placing greater emphasis on technology development.

INL's Technology Deployment is an integral part of "delivering the goods." By working with INL's talented scientists, engineers and researchers who consistently deliver amazing discoveries, innovative inventions and significant technological advances, Technology Deployment strives to ensure the investments in INL translate to products and tangible public benefit.

As one of Secretary Chu's multi-program national laboratories, Idaho National Laboratory has a statutory requirement to make its capabilities and technologies available to federal agencies, state and local governments, universities and industry. This requirement adds urgency and importance to facilitating the transfer of research results and technologies from INL so the public can benefit through job creation and new technologies that improve our quality of life.

INL's mission is to conduct research and development in three main focus areas: energy, with a special emphasis on nuclear energy; homeland and national security focusing on critical infrastructure protection; and general energy and environment sciences and technology. The Director's letter detailed the statistics for this year. What follows is a summary of the process INL uses to "deliver the goods."

The transfer of new technologies follows a clear path. Beginning with discovery and invention, researchers confer with Commercialization Managers to ensure that the new intellectual property is captured, protected and deployed. This is accomplished through a disciplined review system where Invention Disclosure Records (IDR) are submitted to learn whether the INL discovery is new or already protected. Then, INL's Technology Exploitation Strategy Team (TEST) evaluates, selects and determines a strategic approach for determining how to exploit the new technology, while the Business-area Exploitation Strategy Teams (BEST) identify and evaluate appropriate approaches to licensing the technology. Working together these teams integrate the management of this intellectual property to ensure it is developed according to

INL's strategic plans and that it is systematically disclosed to promote commercialization fully, timely, and appropriately.

Technology Deployment also strives to provide unique or special INL capabilities to federal agencies, companies and universities to solve specific technical challenges through its Work for Others program. INL employees work cooperatively with researchers and other technical staff world wide to solve the world's most challenging problems through its Cooperative Research and Development program.

The impact of these efforts can be significant and surprising in their reach. For example, INL researchers applied their separations skills from nuclear fuel design efforts to develop the award-winning Nano-Composite Arsenic Sorbent (N-CAS) technology that removes arsenic from contaminated water supplies. This recently licensed technology will assist more than 70 million people around the world in countries like Bangladesh, as well as more than 4,000 U.S. communities and 14 million homeowners, whose water resources exceed safe standards.

This annual report catalogs INL's deployment of technology through a variety of transactions and commercialization activities. It includes significant detail about the hard work of INL researchers in creating intellectual property, a summary of licensing agreements, a listing of Cooperative Research and Developments Agreements (CRADAs), a summary of major Work For Others programs (WFO), and the regional impact of Technology Based Economic Development activities, including the Technical Assistance Program.

This has been a year of fundamental change for Technology Deployment, complemented by significant positive performance. We continue to implement improvements in structure, performance, and compliance. But most importantly, we are focused on teaming with our research and development leadership, looking for ways to make positive contributions to their research and business operations. With these improvements in mind, we are looking forward to making additional and sustainable deployment contributions within INL during FY 2010.

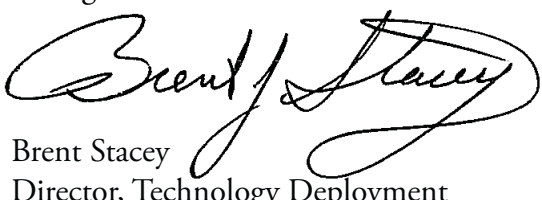

Director, Technology Deployment 

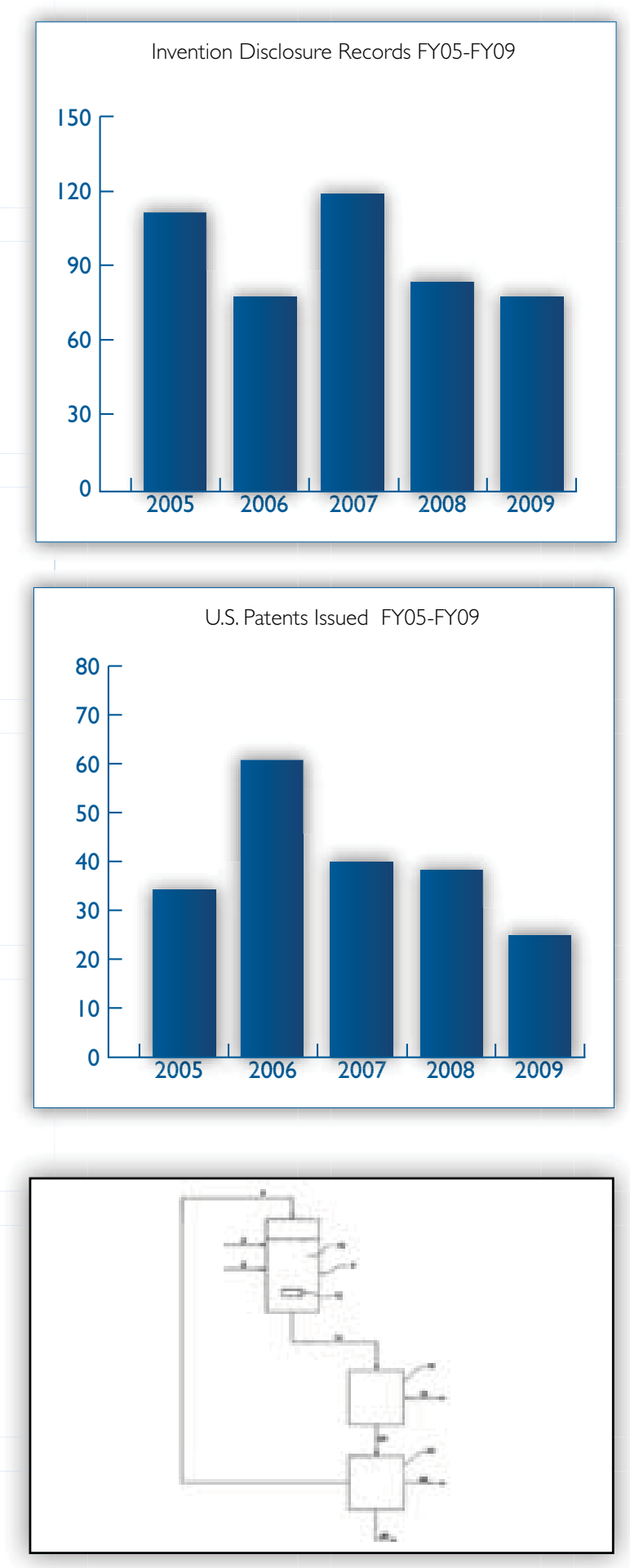

\section{Intellectual Property}

Requested and granted copyrights, filed patent applications and issued patents compose the Intellectual Property (IP) that Idaho National Laboratory uses as the foundation for interactions between national laboratories and other parties. The annual and accumulated portfolio of IP often is the basis of measuring much of what technology deployment offers to the public.

Technology Deployment works closely with researchers and management of INL's directorates to identify and pursue technology commercialization and business development opportunities. In 2009, 77 invention disclosures were submitted to Battelle Energy Alliance (BEA) by INL inventors and 25 U.S. patents were issued either to INL or DOE based on the inventions of INL scientists and researchers.

BEA has the right under its contract, subject to some exceptions, to take title to inventions and seek patent protection. The decision of whether or not to take title and seek patent protection is based on market and technical assessments of the technology and its subsequent programmatic value. Market assessments are performed and a recommendation is presented to a committee comprised of department or project managers, assistant lab director or designee, market analysts, commercialization managers, and patent attorneys. These recommendations are presented before the team, where a final decision is made to elect or decline the technology for patent protection. Generally, if the invention is judged as commercially valuable, crucial to a primary mission, or valuable in terms of motivating further research funding, it is elected. If BEA decides to decline title, DOE decides on whether to seek patent protection in its own name. If DOE decides not to seek patent protection, the inventor(s) may petition to have title waived to them by DOE with the expectation that they will pursue patent protection using their own resources.

A brief description of each patent issued during FY 2009 based on INL inventions is provided on the following pages.

\section{Production of Biodiesel Using Expanded Gas Solvents}

Daniel M. Ginosar, Lucia Petkovic, and Robert V. Fox were issued a patent for a method of producing an alkyl ester involving an alcohol and a triglyceride or fatty acid. An expanding gas is dissolved into the alcohol to form a gas expanded solvent. The alcohol is reacted with the triglyceride or fatty acid in a single phase to produce the alkyl ester. The expanding gas may be a nonpolar expanding gas, such as carbon dioxide, methane, ethane, propane, butane, pentane, ethylene, propylene, butylene, pentene, isomers thereof, and mixtures thereof, which is dissolved into the alcohol. The gas expanded solvent may be maintained at a temperature below, at, or above a critical temperature of the expanding gas and at a pressure below, at, or above a critical pressure of the expanding gas.

Patent Number: 7,514,575

Date Issued: April 7, 2009 


\section{Enhancement of Alkylation Catalysts for Improved Supercritical Fluid Regeneration}

Daniel M. Ginosar and Lucia Petkovic were issued a patent for a method of modifying an alkylation catalyst to reduce the formation of condensed hydrocarbon species thereon. The method provides an alkylation catalyst comprising a plurality of active sites. The plurality of active sites on the alkylation catalyst may include a plurality of weakly acidic active sites, intermediate acidity active sites, and strongly acidic active sites. A base is adsorbed to a portion of the plurality of active sites, such as the strongly acidic active sites, selectively poisoning the strongly acidic active sites. A method of modifying the alkylation catalyst by providing an alkylation catalyst comprising a pore size distribution that sterically constrains formation of the condensed hydrocarbon species on the alkylation catalyst or by synthesizing the alkylation catalyst to comprise a decreased number of strongly acidic active sites is also disclosed, as is a method of improving a regeneration efficiency of the alkylation catalyst.

Patent Number: 7,592,282

Date Issued: Sep. 22, 2009

\section{Apparatus for the Liquefaction of Natural Gas and Methods} Relating to Same

Bruce M. Wilding, Michael G. McKellar, and Terry D. Turner were issued a patent for an apparatus and method for producing liquefied natural gas. A liquefaction plant may be coupled to a source of unpurified natural gas, such as a natural gas pipeline at a pressure letdown station. A portion of the gas is drawn off and split into a process stream and a cooling stream. The cooling stream passes through an expander creating work output. A compressor may be driven by the work output and compresses the process stream. The compressed process stream is cooled, such as by the expanded cooling stream. The cooled, compressed process stream is expanded to liquefy the natural gas. A gas-liquid separator separates the vapor from the liquid natural gas. A portion of the liquid gas is used for additional cooling. Gas produced within the system may be recompressed for reintroduction into a receiving line or recirculation within the system for further processing.
Patent Number: 7,591,150
Date Issued: Sep. 22, 2009

\section{Apparatus for the Liquefaction of Natural Gas and Methods Relating to Same}

Bruce M. Wilding, Francis Carney, Michael G. McKellar, and Terry D. Turner were issued a patent for an apparatus and method for producing liquefied natural gas. A liquefaction plant may be coupled to a source of unpurified natural gas, such as a natural gas pipeline at a pressure letdown station. A portion of the gas is drawn off and split into a process stream and a cooling stream. The cooling stream passes through an expander creating work output. A compressor may be driven by the work output and compresses the process stream. The compressed process stream is cooled, such as by the expanded cooling stream. The cooled, compressed process stream is divided into first and second portions with the first portion being expanded to liquefy the natural gas. A gas-liquid separator separates the vapor from the liquid natural gas. The second portion of the cooled, compressed process stream is also expanded and used to cool the compressed process stream.

Patent Number: 7,594,414

Date Issued: Sep. 29, 2009
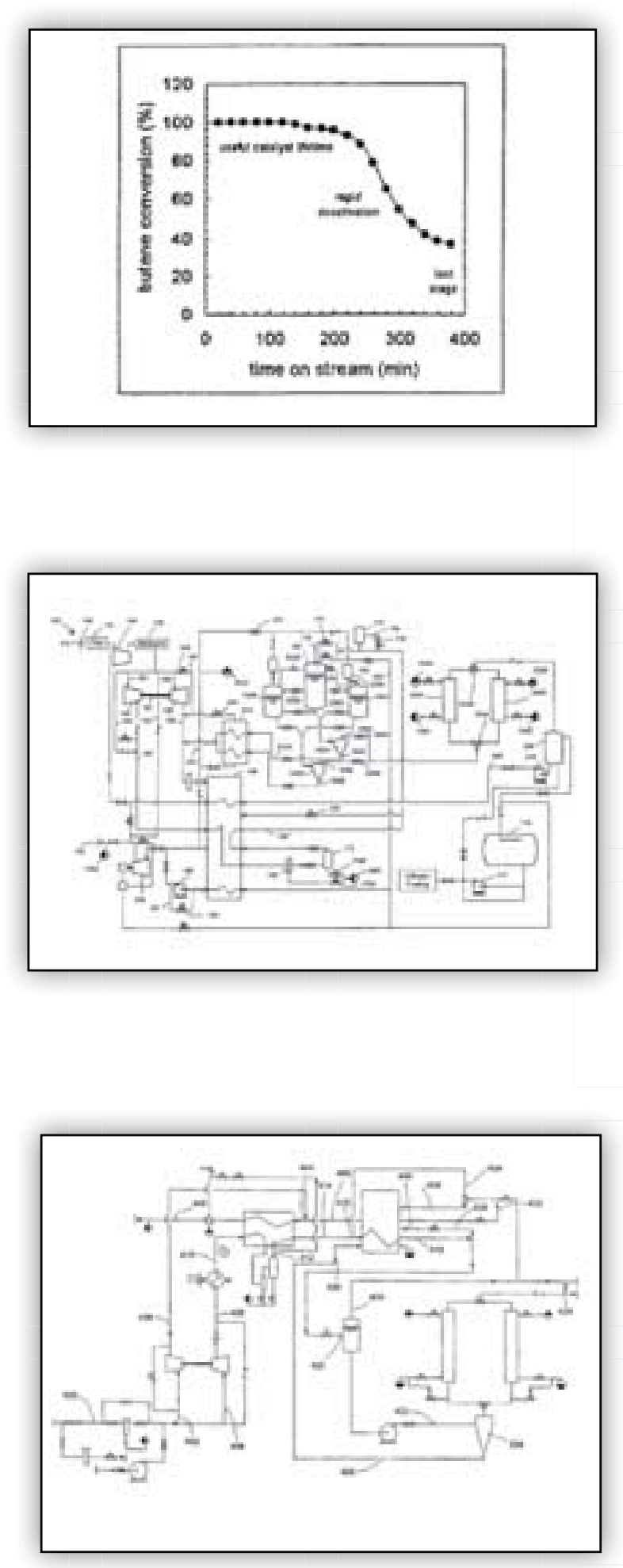

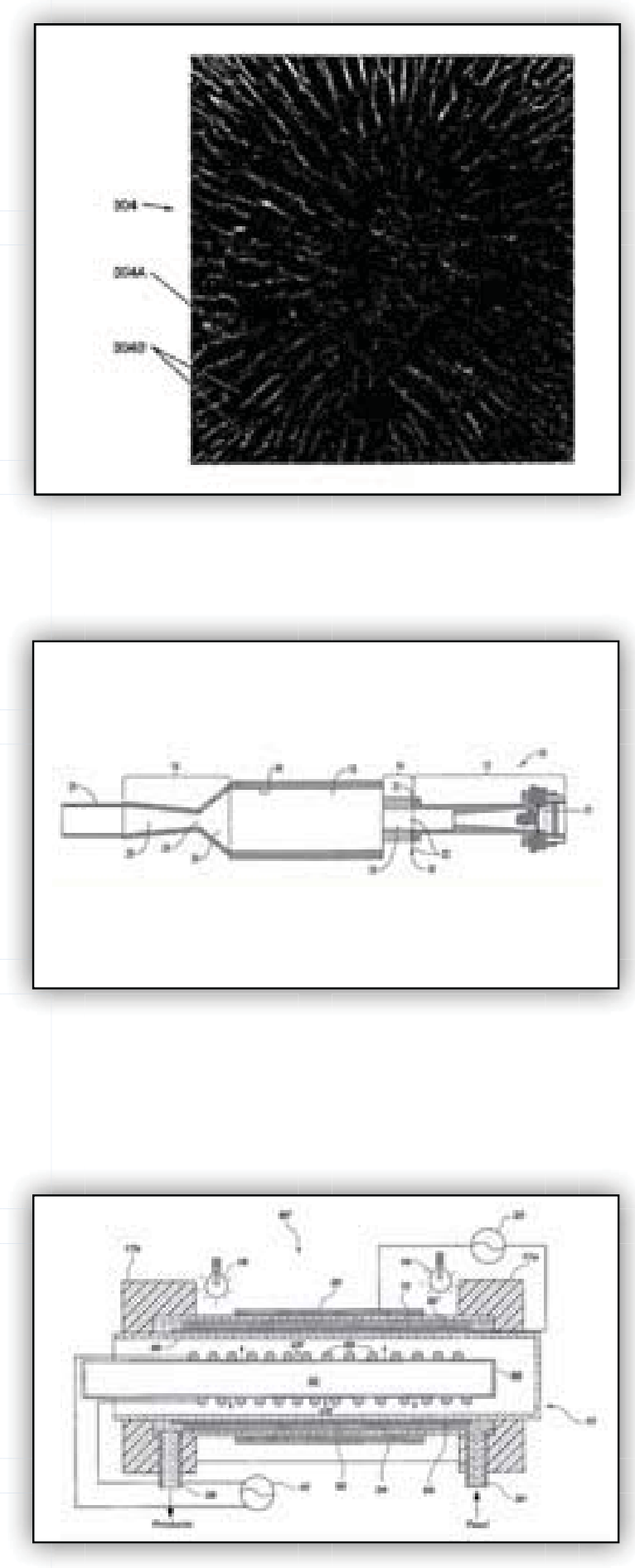

\section{Ion Processing Element with Composite Media}

Ferdinand Sebesta, Nicholas R. Mann, Terry A. Todd, and Troy J. Tranter were issued a patent for an ion processing element employing composite media disposed in a porous substrate, for facilitating removal of selected chemical species from a fluid stream. The ion processing element includes a porous fibrous glass substrate impregnated by composite media having one or more active components supported by a matrix material of polyacrylonitrile. The active components are effective in removing, by various mechanisms, one or more constituents from a fluid stream passing through the ion processing element. Due to the porosity and large surface area of both the composite medium and the substrate in which it is disposed, a high degree of contact is achieved between the active component and the fluid stream being processed. Further, the porosity of the matrix material and the substrate facilitates use of the ion processing element in high volume applications where it is desired to effectively process a high volume flows.

Patent Number: 7,507,340

Date Issued: March 24, 2009

\section{Thermal Synthesis Apparatus}

Brent A. Detering and James R. Fincke were issued a patent for an apparatus for thermal conversion of one or more reactants to desired end products includes an insulated reactor chamber having a high temperature heater such as a plasma torch at its inlet end and, optionally, a restrictive convergent-divergent nozzle at its outlet end. In a thermal conversion method, reactants are injected upstream from the reactor chamber and thoroughly mixed with the plasma stream before entering the reactor chamber. The reactor chamber has a reaction zone that is maintained at a substantially uniform temperature. The resulting heated gaseous stream is then rapidly cooled by passage through the nozzle, which "freezes" the desired end product(s) in the heated equilibrium reaction stage, or is discharged through an outlet pipe without the convergent-divergent nozzle. The desired end products are then separated from the gaseous stream.

Patent Number: 7,576,296

Date Issued: Aug. 18, 2009

\section{Methods for Natural Gas and Heavy Hydrocarbon Co-Conversion}

Brent A. Detering, Lee O. Nelson, and Peter C. Kong were issued a patent for a reactor for reactive co-conversion of heavy hydrocarbons and hydrocarbon gases and includes a dielectric barrier discharge plasma cell having a pair of electrodes separated by a dielectric material and passageway therebetween. An inlet is provided for feeding heavy hydrocarbons and other reactive materials to the passageway of the discharge plasma cell, and an outlet is provided for discharging reaction products from the reactor. A packed bed catalyst may optionally be used in the reactor to increase efficiency of conversion. The reactor can be modified to allow use of a variety of light sources for providing ultraviolet light within the discharge plasma cell. Methods for upgrading heavy hydrocarbons are also disclosed.

Patent Number: 7,494,574

Date Issued: Feb. 24, 2009 
Methods for Producing Cermet Materials and Methods of Utilizing Same

Peter C. Kong was issued a patent for methods of fabricating cermet materials and methods of utilizing the same such as in filtering particulate and gaseous pollutants from internal combustion engines having intermetallic and ceramic phases. The cermet material may be made from a transition metal aluminide phase and an alumina phase. The mixture may be pressed to form a green compact body and then heated in a nitrogen containing atmosphere so as to melt aluminum particles and form the cermet. Filler materials may be added to increase the porosity or tailor the catalytic properties of the cermet material. Additionally, the cermet material may be reinforced with fibers or screens. The cermet material may also be formed so as to pass an electrical current therethrough to heat the material during use.

Patent Number: 7,470,393

Date Issued: Dec. 30, 2008

\section{System for Recovery of Daughter Isotopes from a Source Material}

Joseph P. Henscheid, Leroy C. Lewis, Terry A. Todd, and Troy J. Tranter were issued a patent for the invention, which includes a method of separating isotopes from a mixture containing at least two isotopes in a solution. A first isotope is precipitated and is collected from the solution. A daughter isotope is generated and collected from the first isotope. The invention includes a method of producing an actinium-225/bismuth-213 product from a material containing thorium-229 and thorium-232. A solution is formed containing nitric acid and the material and iodate is added to form a thorium iodate precipitate. A supernatant is separated from the thorium iodate precipitate and a second volume of nitric acid is added to the precipitate. The precipitate is stored and a decay product comprising actinium-225 and bismuth-213 is generated in the second volume of nitric acid which is then separated from the thorium iodate precipitate, filtered, and treated using at least one chromatographic procedure. The invention also includes a system for producing an actinium-225/bismuth-213 product.

Patent Number: 7,569,192

Date Issued: Aug. 4, 2009

\section{Improved Subsurface Drill String}

Blair K. Grover, Craig A. Seymour, Don T. Clark, Rodney O. Mathewson, and William L. Casper (deceased) were issued a patent for a sealed probe casing that is specifically designed to assist researchers during the placement of instruments into highly contaminated waste sites. The casing is able to withstand extreme forces without allowing dangerous contaminates to escape the surface.

Patent Number: 7,431,348

Date Issued: Oct. 7, 2008
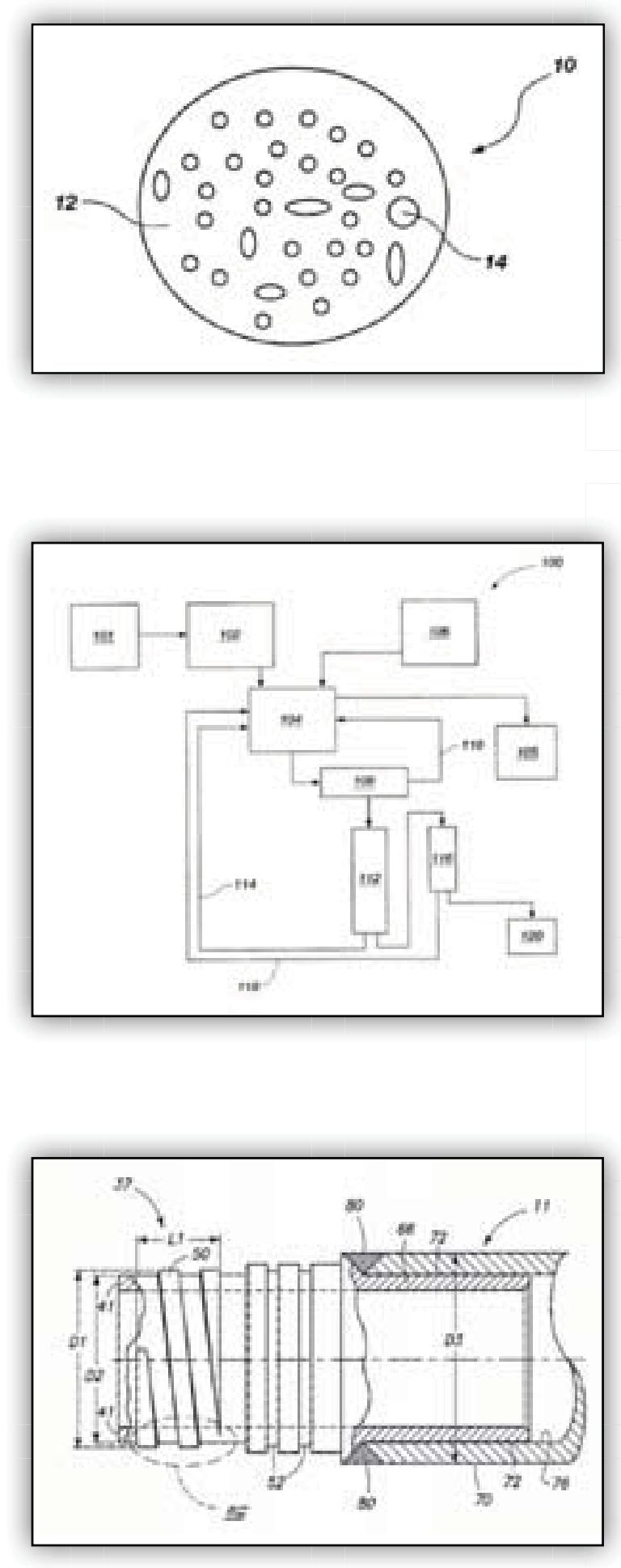


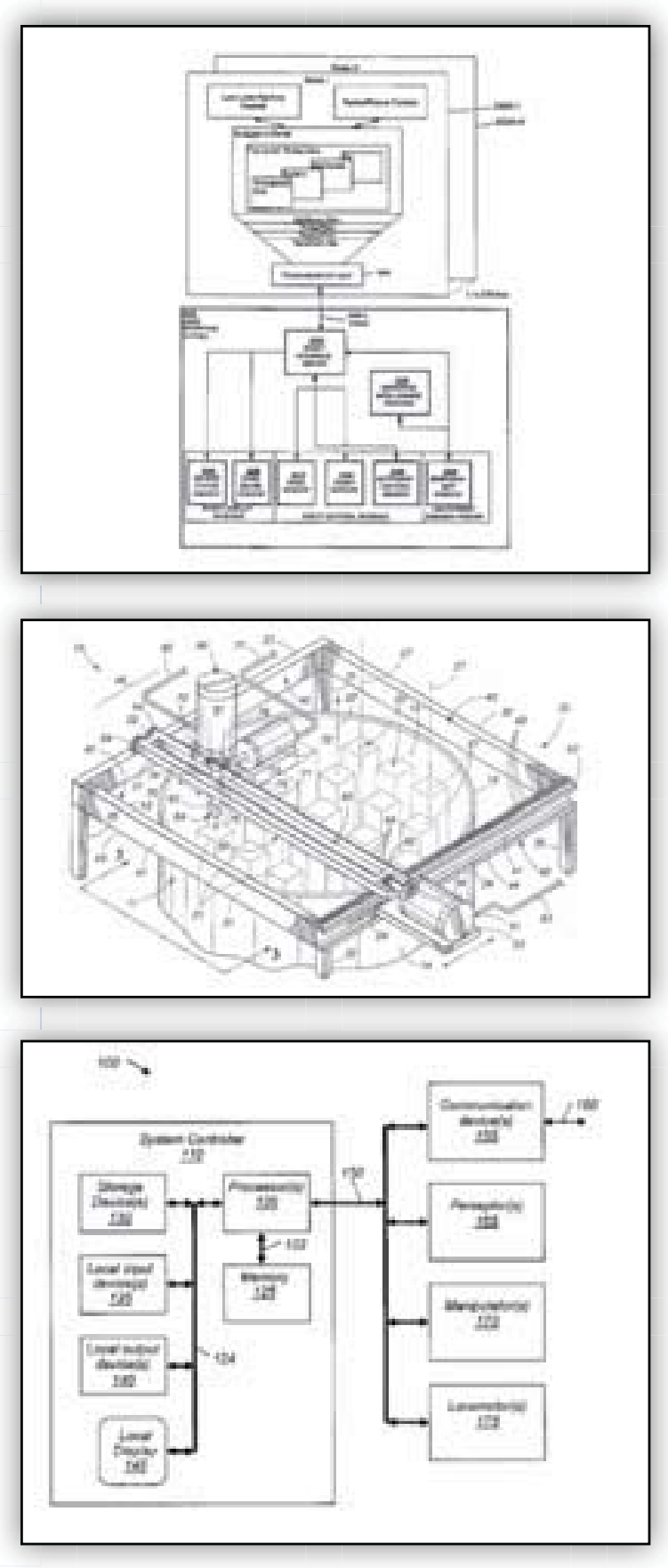

\section{Occupancy Change Detection System and Method}

David J. Bruemmer and Douglas A. Few were issued a patent for robot platforms, methods, and computer readable media. The robot platform includes perceptors, locomotors, and a system controller. The system controller executes instructions for producing an occupancy grid map of an environment around the robot, scanning the environment to generate a current obstacle map relative to a current robot position, and converting the current obstacle map to a current occupancy grid map. The instructions also include processing each grid cell in the occupancy grid map. Within the processing of each grid cell, the instructions include comparing each grid cell in the occupancy grid map to a corresponding grid cell in the current occupancy grid map. For grid cells with a difference, the instructions include defining a change vector for each changed grid cell, wherein the change vector includes a direction from the robot to the changed grid cell and a range from the robot to the changed grid cell.

Patent Number: 7,584,020

Date Issued: Sep. 1, 2009

\section{A Detector and Method for Inspecting A Sealed Nuclear Storage Container}

Augustine J. Caffrey was issued a patent for a detector and methodology for inspecting a sealed nuclear storage container. It includes a collimated gamma-ray radiation detector, which is moveably borne by the sealed nuclear storage container and detects gamma-ray radiation emitted by a plurality of spent nuclear fuel sources. This technology inspects containers for purposes of detecting the illicit or unauthorized removal of spent nuclear fuel.

Patent Number: 7,514,695 Date Issued: April 7, 2009

\section{Autonomous Navigation System and Method}

David J. Bruemmer and Douglas A. Few were issued a patent for Robot platforms, methods, and computer media are disclosed. The robot platform includes perceptors, locomotors, and a system controller, which executes instructions for autonomously navigating a robot. The instructions repeat, on each iteration through an event timing loop, the acts of defining an event horizon based on the robot's current velocity, detecting a range to obstacles around the robot, testing for an event horizon intrusion by determining if any range to the obstacles is within the event horizon, and adjusting rotational and translational velocity of the robot accordingly. If the intrusion occurs, rotational velocity is modified by a proportion of the current rotational velocity reduced by a proportion of the range to the nearest obstacle and translational velocity is modified by a proportion of the range to the nearest obstacle. If no intrusion occurs, translational velocity is set as a ratio of a speed factor relative to a maximum speed.

Patent Number: 7,587,260

Date Issued: Sep. 8, 2009 
Methods of Forming Aluminum Oxynitride Bodies, including Method of Forming a Sheet of Transparent Armor

Henry S. Chu and Thomas M. Lillo were issued patents for the invention that includes methods of forming an aluminum oxynitride-comprising body. For example, a mixture is formed which comprises A:B:C in a respective molar ratio in the range of 9:3.6-6.2:0.1-1.1, where " $\mathrm{A}$ " is $\mathrm{Al} 2 \mathrm{O} 3$, "B" is $\mathrm{AlN}$, and "C" is a total of one or more of $\mathrm{B} 2 \mathrm{O} 3, \mathrm{SiO} 2$, $\mathrm{Si}-\mathrm{Al}-\mathrm{O}-\mathrm{N}$, and $\mathrm{TiO} 2$. The mixture is sintered at a temperature of at least $1,600^{\circ} \mathrm{C}$ at a pressure of no greater than 500 psia effective to form an aluminum oxynitride-comprising body which is at least internally transparent and has at least 99\% maximum theoretical density.

Patent Number: 7,459,122

Date Issued: Dec.2, 2008

\section{Apparatus and Method for Inspecting a Sealed Container}

Alan Wolfe Hunt, J. Frank Harmon, James L. Jones, Michael Smith, and Randy J. Spaulding were issued a patent for an apparatus to inspect a sealed container. It includes a pulsed electron accelerator which is positioned on one side of the sealed container to produce a pulsed beam of photons, which passes through the sealed container and any contents within the sealed container. A detector positioned to the opposite side of the sealed container receives the pulsed beam of photons to produce an output signal. This develops a visible image from the output signal of the detector, depicting the contents of the sealed container.

Patent Number: 7,508,909

Date Issued: March 24, 2009

\section{Portable Receiver for Radar Detection}

Chris Lopes and Dale K. Kotter were issued a patent for various embodiments relating to a portable antenna-equipped device for multi-band radar detection. The detection device includes a plurality of antennas on a flexible substrate, a detection-and-control circuit, an indicator and a power source. The antenna may include one or more planar lithographic antennas that may be fabricated on a thin-film substrate. Each antenna may be tuned to a different selection frequency or band. The antennas may include a bolometer for radar detection. Each antenna may include a frequency selective surface for tuning to the selection frequency.

Patent Number: 7,436,373

Date Issued: Oct. 14, 2008

\section{Continuous Sampling Ion Mobility Spectrometers and Methods Therefore}

Anthony D. Appelhans, David A. Dahl, Jill R. Scott, John E. Olson, and Timothy R. McJunkin were issued a patent for an ion mobility spectrometer may include a flow channel having inlet and outlet ends. A deflection electrode is positioned within the flow channel so that a non-linear electric field is created between at least a portion of the flow channel and at least a portion of the deflection electrode when an electrostatic potential is placed across the deflection electrode and the flow channel. The ion mobility spectrometer also includes means for producing ions at a position upstream from the leading edge of the deflection electrode, so that ions produced thereby are deflected by the deflection electrode into the non-linear electric field. A detector positioned within the flow channel for detects ions from the non-linear electric field.

Patent Number: 7,518,105

Date Issued: April 14, 2009
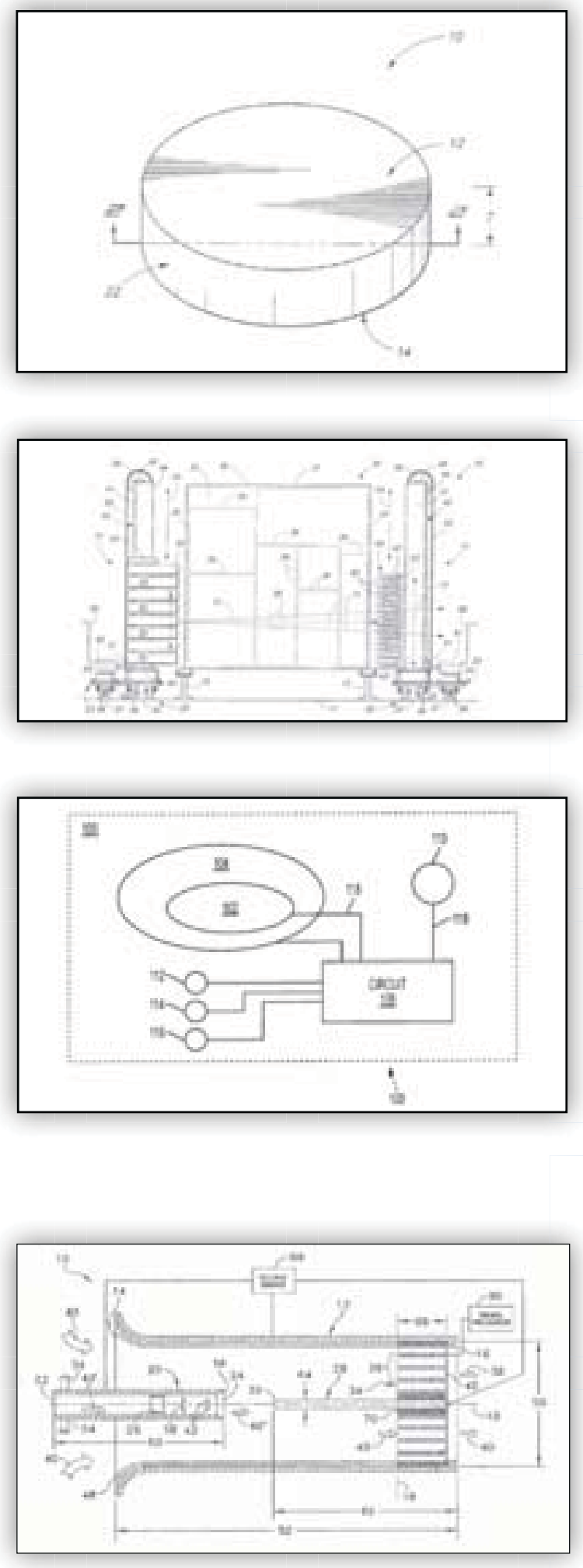

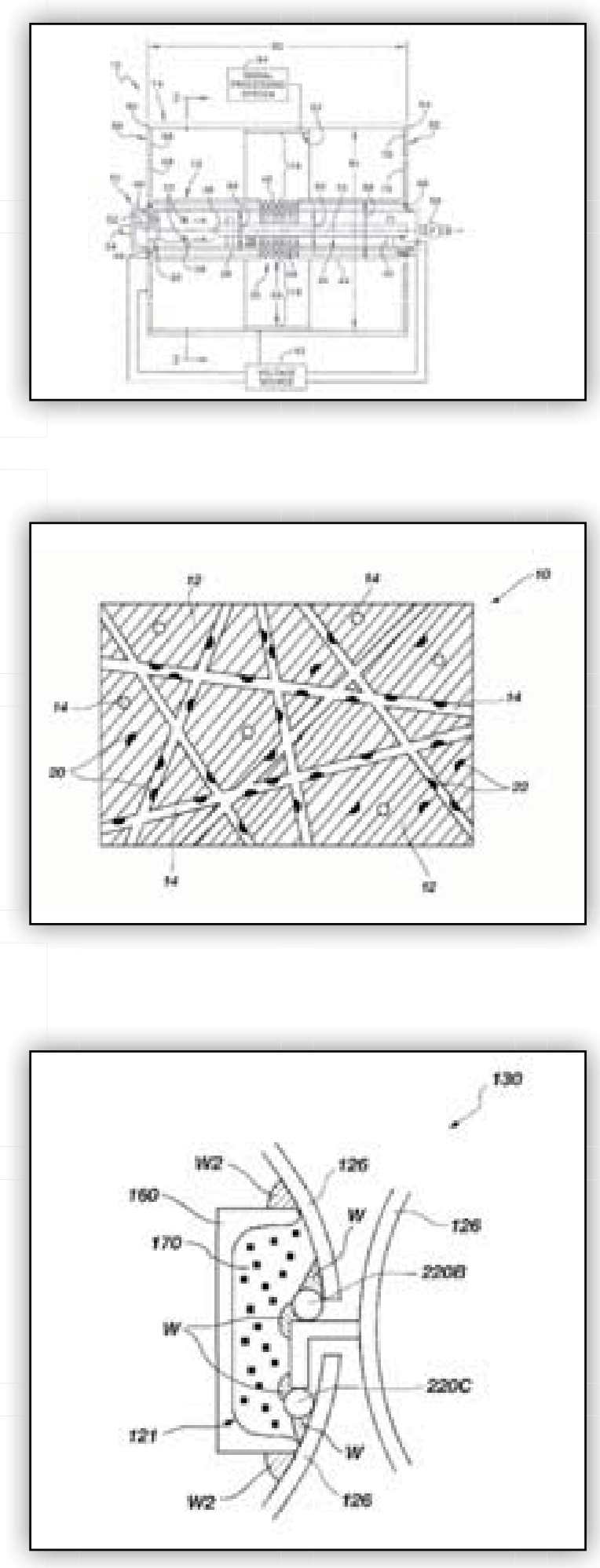

\section{Ion Mobility Spectrometers and Methods for Ion Mobility Spectrometry}

Anthony D. Appelhans, David A. Dahl, Jill R. Scott, John E. Olson, and Timothy R. McJunkin were issued a patent for an ion mobility spectrometer, which may include an inner electrode and an outer electrode. It is arranged so that at least a portion of the outer electrode surrounds at least a portion of the inner electrode and defines a drift space therebetween. The inner and outer electrodes are electrically insulated from one another so that a non-linear electric field is created in the drift space when an electric potential is placed on the inner and outer electrodes. An ion source operatively associated with the ion mobility spectrometer releases ions to the drift space defined between the inner and outer electrodes. A detector operatively associated with at least a portion of the outer electrode detects ions from the drift space.

Patent Number: 7,518,106

Date Issued: April 14, 2009

\section{A Precursor of a Catalytic Structure, a Method of Fabricating the Same, and a System and a Method for Using the Same}

Daniel M. Ginosar, Harry Whittier Rollins, and Lucia Petkovic were issued a patent for a precursor to a catalytic structure comprising zinc oxide and copper oxide. The zinc oxide has a sheet-like morphology or a spherical morphology and the copper oxide comprises particles of copper oxide. The copper oxide is reduced to copper, producing the catalytic structure. The catalytic structure is fabricated by a hydrothermal process. A reaction mixture comprising a zinc salt, a copper salt, a hydroxyl ion source, and a structure-directing agent is formed. The reaction mixture is heated under confined volume conditions to produce the precursor. The copper oxide in the precursor is reduced to copper. A method of hydrogenating a carbon oxide using the catalytic structure is also disclosed, as is a system that includes the catalytic structure.

Patent Number: 7,592,291

Date Issued: Sep. 22, 2009

Subterranean Barriers, Methods and Apparatuses for Forming, Inspecting, Selectively Heating and Repairing Same

John G. Richardson, Kevin M. Kostelnik, Paul A. Sloan, Reva A.

Nickelson, and Stephanie Walsh were issued a patent for a subterranean barrier and method for forming same. The barrier includes a plurality of casing strings wherein at least one casing string of the plurality of casing strings may be affixed to at least another adjacent casing string of the plurality of casing strings through at least one weld, at least one adhesive joint, or both. A method and system for nondestructively inspecting a subterranean barrier is disclosed. For instance, a radiographic signal may be emitted from within a casing string toward an adjacent casing string and the radiographic signal may be detected from within the adjacent casing string. A method of repairing a barrier including removing at least a portion of a casing string and welding a repair element within the casing string is disclosed. A method of selectively heating at least one casing string forming at least a portion of a subterranean barrier is disclosed.

Patent Number: 7,513,715

Date Issued: April 7, 2009 


\section{Method for Protecting an Electric Generator}

Barry W. Kuehnle, Jeffrey B. Roberts, and Ralph W. Folkers were issued a patent for a method for protecting an electrical generator, which includes an electrical generator normally synchronously operated with an electrical power grid. It also provides a synchronizing signal from the electrical generator to establish a reference signal and electrically isolates the electrical generator from the electrical power grid, if the synchronizing signal is not in phase with the reference signal.

Patent Number: 7,453,674

Date Issued: Nov.18, 2008

\section{Method and System for Detecting Explosives}

Andrew J. Edwards, Edward H.. Seabury, Edward L. Reber, James K. Jewell, Kenneth W. Rohde, Kurt W. Derr, and Larry G. Blackwood were issued a patent for a method of detecting explosives in a vehicle, which includes providing a first rack on one side of the vehicle with a neutron generator and a plurality of gamma ray detectors. A rack on another side of the vehicle also includes a neutron generator and a plurality of gamma ray detectors. A control system, remote from the first and second racks, is coupled to the neutron generators and gamma ray detectors. The system looks for a signature indicative of presence of an explosive.

Patent Number: 7,501,637

Date Issued: March 10, 2009

\section{Methods of Stripping Metals from Organic Solvents}

Igor V. Smirnov, Jack D. Law, R (Scott) S. Herbst, Terry A. Todd, Valeriy N. Romanovskiy, Vasiliy A. Babain, and Vyacheslav M. Esimantovskiy were issued a patent for a method of stripping radioactive wastes and/or metals from organic solvents in manner that allows the stripping agents to be reclaimed, distilled, and reused. This invention will significantly lower the volume of radioactive waste that would otherwise be immobilized and disposed of in a repository.

Patent Number: 7,494,630

Date Issued: Feb. 24, 2009

\section{Cermet Materials}

Peter C. Kong was issued a patent for a self-cleaning porous cermet material, filter and system that may be used in filtering particulate and gaseous pollutants from internal combustion engines having intermetallic and ceramic phases. The porous cermet filter may be made from a transition metal aluminide phase and an alumina phase. Filler materials may be added to increase the porosity or tailor the catalytic properties of the cermet material. Additionally, the cermet material may be reinforced with fibers or screens. The porous filter may also be electrically conductive so that a current may be passed therethrough to heat the filter during use. Further, a heating element may be incorporated into the porous cermet filter during manufacture. This heating element can be coated with a ceramic material to electrically insulate the heating element. An external heating element may also be provided to heat the cermet filter during use.

Patent Number: 7,468,089

Date Issued: Dec. 23, 2008
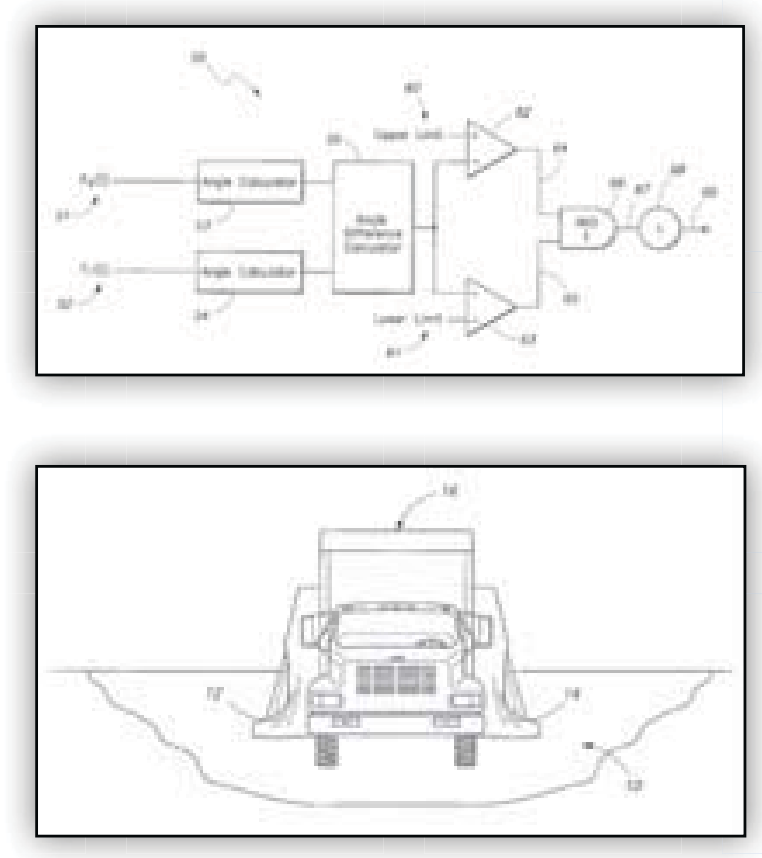

\section{Extractant Composition Including Crown Ether and Calixarene Extractants}

Bruce J. Mincher, Catherine L. Riddle, Christopher McGrath, David H. Meikrantz, Dean R. Peterman, Jack D. Law, John D. Baker (deceased), and Terry A. Todd were issued a patent for an extractant composition comprising a mixed extractant solvent consisting of calix[4] arene-bis-(tert-octylbenzo)-crown-6 ("BOBCalixC6"), 4?,4?,(5?)-di(t-butyldicyclo-hexano)-18-crown-6 ("DtBu18C6"), and at least one modifier dissolved in a diluent. The DtBu18C6 may be present at from approximately $0.01 \mathrm{M}$ to approximately $0.4 \mathrm{M}$, such as at from approximately $0.086 \mathrm{M}$ to approximately $0.108 \mathrm{M}$. The modifier may be 1-(2,2,3,3-tetrafluoropropoxy)-3-(4-sec-butylphenoxy)-2-propanol ("Cs$7 \mathrm{SB}$ ") and may be present at from approximately $0.01 \mathrm{M}$ to approximately $0.8 \mathrm{M}$. In one embodiment, the mixed extractant solvent includes

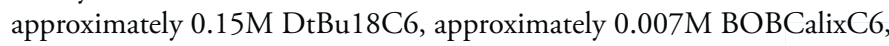
and approximately $0.75 \mathrm{M}$ Cs-7SB modifier dissolved in an isoparaffinic hydrocarbon diluent. The extractant composition further comprises an aqueous phase. The mixed extractant solvent may be used to remove cesium and strontium from the aqueous phase.

Patent Number: 7,524,469

Date Issued: April 28, 2009 


\section{Granted Copyrights}

\section{INL received permission to assert copyright for six newly developed software capabilities.}

\section{Copyrighted Software}

Power Line Integrity Monitor and Repeater

FPGA-Based Nuclear Material Detection Software

Robotic Intelligence Kernel: Architecture

Robotic Intelligence Kernel: Driver

\begin{tabular}{|l} 
\\
\hline Robotic Intelligence Kernel: Communications \\
\hline Robotic Intelligence Kernel: Visualization
\end{tabular}

\section{Authors}

John M. Svoboda, Robert E. Polk

Daren R Norman, James L Jones, Kevin J Haskell, Randy J.

Spaulding

Christopher McFarland, Curtis W Nielsen, David J

Bruemmer, Douglas A Few, Miles CWalton, Robert A

Kinoshita, Victor G Walker

Amit Kulkarni, Curtis W Nielsen, David J Bruemmer, Douglas

A Few, Matthew O Anderson, Miles CWalton, Robert A

Kinoshita, Victor G Walker

Miles CWalton

Amit Kulkarni, Curtis W Nielsen, John Alan Atherton, Jonathon Whetton
Power Line Integrity Monitor and Repeater. INL has developed a power system integrity monitor and repeater that provide real time status of the integrity of the physical structure of power poles and transmission towers. It may be applied to other structures, such as pipelines or cell towers, which have multiple segments that can cover hundreds of miles. Sensors and on-board processing provide indication of tampering or impending damage to the structure with information provided to the central operations center or supervisory control and data acquisition (SCADA) for mitigation.

This software runs on a series of small, inexpensive, low power electronic sensor platforms that are mounted on each tower of an electric power transmission or distribution system for the purpose of communicating system integrity to a central location. The software allows each platform to:

1) interface with sensors that monitor tower integrity,

2) record and analyze events,

3) communicate sensor information to other sensor platforms located on adjacent towers or to a central monitoring location, and

4) derive, conserve, and store platform power from the transmission of electric power.
FPGA-Based Nuclear Material Detection Software. This software uses signals from the Pulsed Photonuclear Neutron Detector (PNND) to determine if nuclear material is present based on natural background levels.

Robotic Intelligence Kernel: Four innovations for the INL's RIK were copyrighted, including:

- A multi-level architecture that supports a dynamic autonomy structure to coalesce hardware for sensing and action as well as software components for perception, communication, behavior and world modeling.

- A driver built on top of the architecture to implement a dynamic autonomy structure. It orchestrates hardware for sensing and action as well as software components to provide intrinsic intelligence for a wide variety of unmanned ground vehicle systems.

- Communications server that transmits information between one or more robots using the RIK and one or more user interfaces, which supports event handling and multiple hardware communication protocols.

- Visualization software to support the user interface and illustrates the data in a 3D display and provides an operating picture wherein the user can task the robot. 


\section{Royalties}

Royalties have more than doubled during the past five years at INL, increasing from about $\$ 800,000$ in fiscal year 2005 to more than $\$ 1.6$ million in fiscal year 2009. This steady growth reflects an expanding portfolio of intellectual property and increased attention to commercialization of these discoveries and inventions.

Legislation governing INL technology transfer activities authorizes the laboratory to retain and use funds generated through the licensing of technology. This licensing income can be used in a variety of ways, including monetary rewards to encourage inventors in their research and further investment in developing and transferring technologies from the Laboratory into the marketplace.

During the past five years INL earned more than $\$ 5.8$ million and during fiscal year 2009 licensed intellectual property generated a record amount of income for one year with more than $\$ 1.6$ million. The generation of these significant monetary returns demonstrates that INL-developed technologies are competitive in commercial markets. The licensing of more than 450 technologies from FY 2005 to FY 2009 and the significant economic impact these transactions have made underscores that INL is succeeding in its mission to transfer technologies to the public.

INL has strategically invested the income retained from licensing activities to pay expenses incidental to the administration and licensing of intellectual property, fund additional mission-related research and development, reward other laboratory employees who contribute significantly to the transfer and utilization of INL technology, employ education and training related to the research and development mission, and other activities that increase the licensing potential of laboratory technology.

In its short history, INL's Innovation Development Fund has been very successful in its objective to enhance the likelihood of transferring laboratory developed technologies to nonfederal parties to meet the purposes of technology transfer legislation. IDF projects have also brought INL technology closer to the market so that the U.S. public can benefit from INL research. A large part of the fund's success my be attributed to the fund's focus on commercial outcome. With nine projects completed by the end of FY-2009, the following projects highlight the the success of the fund:

- Demonstration of an ultrahydrophic surface technology (assisted the formation of a $\$ 1.8 \mathrm{M}$ partnership with GE);

- Demonstration of an oil shale mercury sorption technology (contributed to a $\$ 500 \mathrm{~K}$ follow on demonstration funded by a licensee);

- Prototype of a photovoltaic technology (facilitated a \$3.3M CRADA and license agreement with $\$ 100 \mathrm{~K}$ in annual fees with Precision Nanoparticles);

- Prototype of a wireless monitoring device (facilitated a license agreement with $\$ 100 \mathrm{~K}$ upfront payment); and

- Bench scale demonstration of a catalyst to convert carbon oxides to ethanol and butanol (facilitated a \$5.2M CRADA).

- Demonstration of a microchip antibody profiling technology to uniquely identify individuals for law enforcement and other applications (facilitated a license agreement under negotiation with a $\$ 300 \mathrm{~K}$ upfront fee)

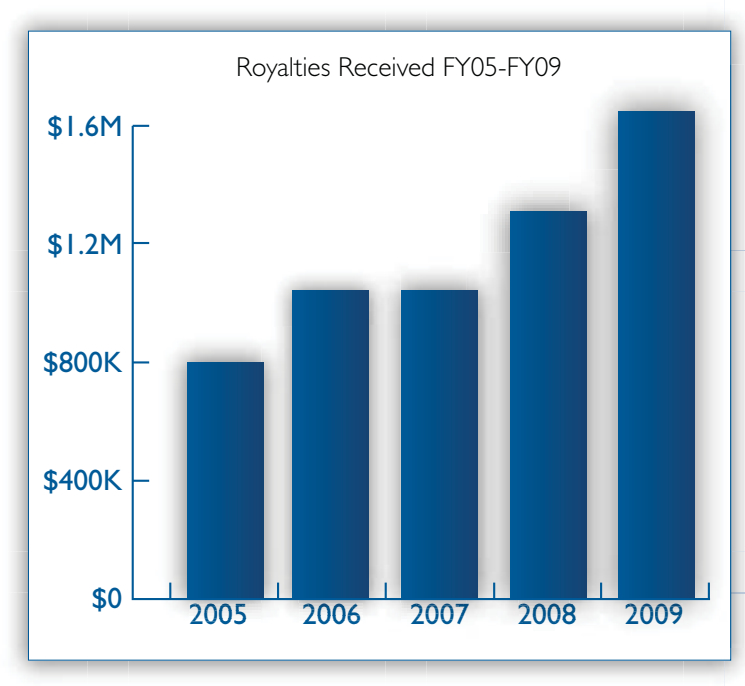

\section{License Agreements}

License agreements between BEA and a business (or other entity) allow the business to reproduce, manufacture, sell, or use INL developed or owned intellectual property. INL contractor owned inventions are available for licensing for commercialization by U.S. and foreign companies and organizations. The INL licenses its intellectual property on much the same terms as universities, other research organizations and industrial firms.

During the past five years, INL has signed 453 licenses that have earned more than $\$ 5.8$ million in royalty fees. For FY 2009, INL signed ten licenses which are listed on page 15 .

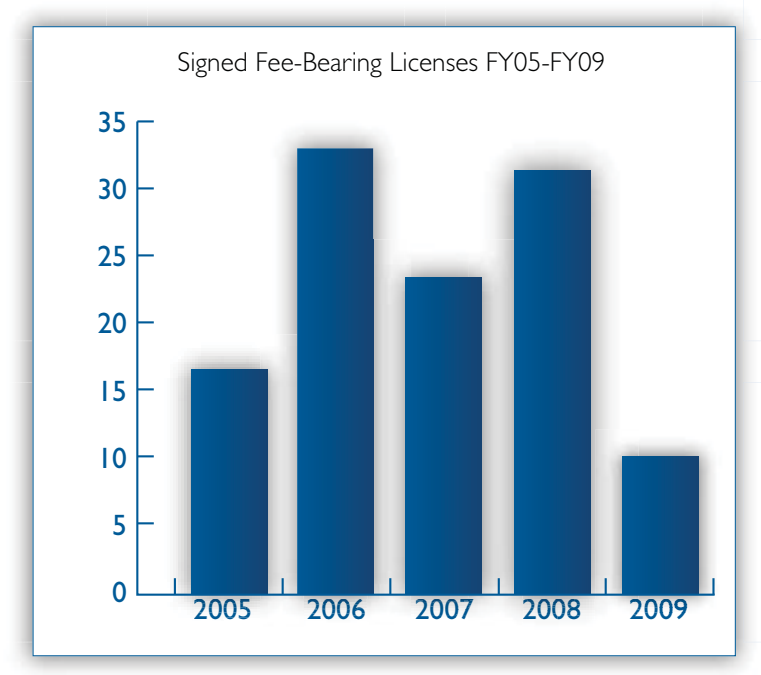




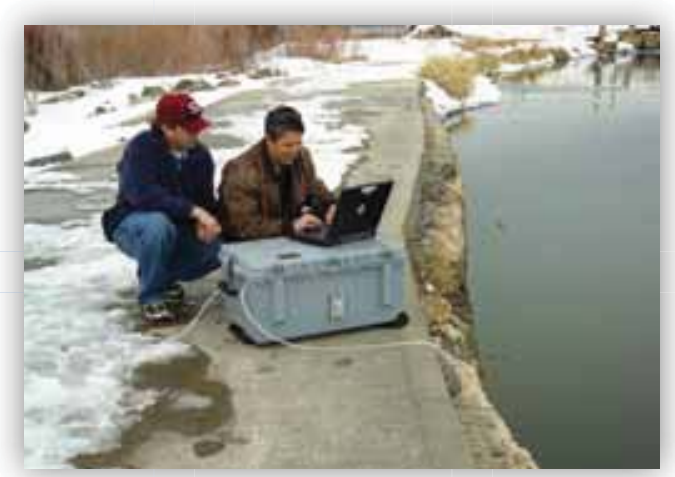

The Water Sample Concentrator is portable, permitting the collection of a sample from a suspected contaminated water source in the field. This technology won a 2009 R\&D 100 Award.

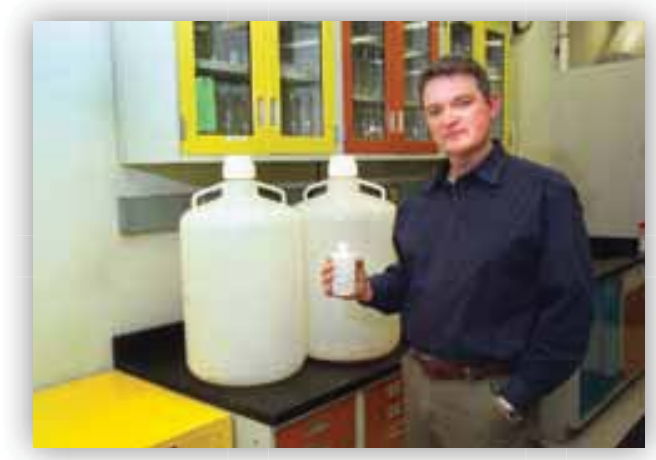

The Water Sample Concentrator technology reduces the required sample size from a suspected contaminated water source from 100 liters weighing about 220 pounds to 250 milliliters that weighs only about one-half a pound.

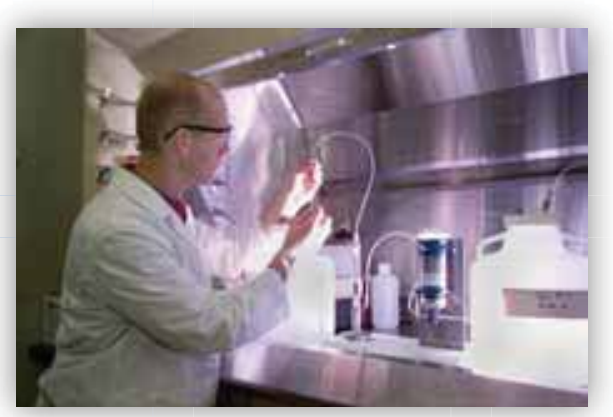

INL researcher Nick Mann, conducting arsenic removal studies using $\mathrm{N}-\mathrm{CAS}$.

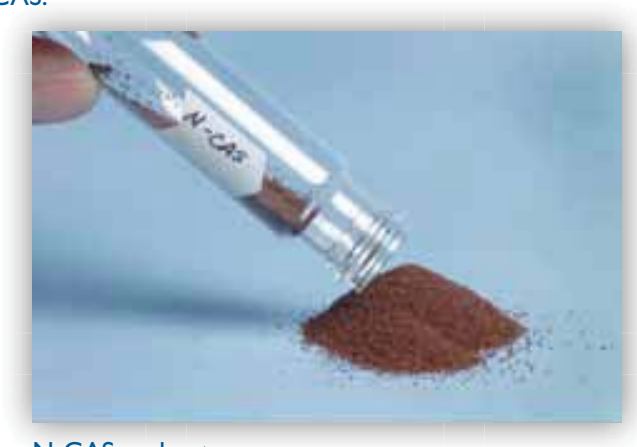

N-CAS sorbent.

\section{Water sampling technology licensed to Teledyne Isco}

Teledyne Isco, Inc., of Lincoln, Nebr. signed a license agreement with INL in Jan. 2009 to commercialize the Water Sample Concentrator, which is a patented technology designed to help safeguard water quality.

Developed jointly by INL and the U.S. Environmental Protection Agency's National Homeland Security Research Center in Cincinnati, WSC is an automated portable device that concentrates and packages a water sample potentially containing waterborne pathogens. This facilitates safe and easy transport to a qualified analytical laboratory, helping safeguard against natural or terrorist-delivered pathogens.

"We are very enthused abo ut this technology," Jonathan Herrmann, director of the EPA's National Homeland Security Research Center, was quoted in an Associated Press news story. He said, "It adds significant capability to test water for harmful contaminants."

"Teledyne Isco is responding to growing market needs," said Teledyne Isco's Director of Innovation, Mike Metcalf. "The WSC technology not only complements our existing products, but allows us to expand into new environmental market opportunities."

"We can portably and remotely collect and concentrate test samples much more quickly than before," said INL Project Manager Mike Carpenter. "Normally, this testing requires about a 27 -gallon water sample, which weighs over 200 pounds. In the past, this large amount of water needed to be transported to a laboratory for concentration and testing."

The concentrator can fit in the trunk of a car and reduces the sample size to about two cups. The collected sample can then be taken to a lab and tested for viruses, bacteria, biohazards, chemicals, toxins and dangerous microorganisms.

"There has been a long-standing need for a portable device to effectively reduce the volume of large samples in the field, while preserving the microorganisms for analysis," said EPA scientist Alan Lindquist. "This technology should enable increased security from potential terrorist or criminal attacks, and also increase the capabilities of water utilities to demonstrate the safety and quality of their water during normal operations."

WSC was selected as a winner in the 2009 competition for a R\&D 100 award in July and announced as an Editor's Choice technology at the awards ceremony in Orlando, Florida in November 2009.

\section{Water Technologies Group signs license for N-CAS}

In Jan. 2009, Water Technology Group Inc., (WTG) Harvard, Mass., signed an exclusive rights a licensing agreement to commercialize the Nano-Composite Arsenic Sorbent (N-CAS) that will improve the ability to remove arsenic from contaminated water supplies and is seven times more effective than current arsenic removal technologies.

In 2006, the Environmental Protection Agency standards reduced the maximum allowable concentration of arsenic in drinking water from 50 parts per billion (ppb) to $10 \mathrm{ppb}$ creating an expensive dilemma for 4,000 American municipalities and nearly 14 million homeowners whose water resources now exceed the new limits. N-CAS will provide an economical method to treat water supplies and meet these new standards.

Signing the license for WTG, Jack Boyles, chief financial officer, said, "Since the EPA lowered the standards for arsenic in drinking water in 2006, we've seen growing public awareness of the health risks of arsenic 
in drinking water and frustration at the lack of effective approaches from the water industry. N-CAS technology will provide affordable, effective and manageable solutions for municipalities, small public water systems and residential systems with arsenic contamination."

INL's project manager, Troy Tranter, who led the team's research efforts, said, "This technology will aid millions of Americans and more than 70 million people around the globe who are exposed to dangerous arsenic concentrations in their drinking water."

A winner of both an international competition for the R\&D 100 award and a Nano-50 award, N-CAS contains high concentrations of arsenic adsorbing nanoparticle metal oxides embedded in a strong composite polymer matrix.

The Water Technology Group (WTG) was established in 2005 to develop and market water purification technologies; and is an affiliate of Northeast Water Solutions, Inc. (NWSI; www.nwsi.net).
Method for Detecting the Presence of Ferromagnetic Objects. EventScreen Holding, Inc, of Irvine, Calif., licensed this INL technology for use in providing security at special events and specific locations.

RELAP5-3D. Two companies, Industrial Leak Detection, Inc, of (insert location) and Unisont Engineering, LLC, and Idaho State University in Pocatello, Idaho signed licenses to use RELAP5-3D.

Method for Production of 99MTC Compositions from 99M003 Containing Materials. NorthStar Medical Radioisotopes, LLC., of Janesville, Wisconsin, licensed this technology to facilitate the production nuclear isotopes for cancer treatment.

Control System Cyber Security Self Assessment Tool (CS2SAT). Industrial Defender, Inc. licensed this technology for further commercialization and deployment.

Vectored Natural Gas and Natural Gas Liquefaction and Liquefier. Solensa SA DE CV licensed both of these technologies for commercialization and deployment in the U.S. and Mexico.

\begin{tabular}{|c|c|}
\hline Licensee & Technology \\
\hline Teledyne Isco, Inc. & $\begin{array}{l}\text { Water Sample Concentrator (Systems and Methods for } \\
\text { Concentrating Substances in Fluid Samples) }\end{array}$ \\
\hline Industrial Leak Detection Inc. & RELAP5-3D \\
\hline NorthStar Medical Radioisotopes, LLC & $\begin{array}{l}\text { Method for Production of } 99 \text { MTC Compositions from } \\
99 \text { M003 Containing Materials }\end{array}$ \\
\hline Industrial Defender, Inc. & Control System cyber Secruity Self Assessment Tool (CS2SAT) \\
\hline Water Technologies Group Inc. & $\begin{array}{l}\text { Nano-Composite Arsenic Sorbent (Removal of Arsenic and } \\
\text { Other Contaminants from Water) }\end{array}$ \\
\hline Unisont Engineering, LLC & RELAP5-3D \\
\hline EventScreen Holding, Inc. & Method for Detecting the Presence of Ferromagnetic Object \\
\hline Idaho State University & ISU RELAP Agreement \\
\hline Solensa SA DE CV & Vectored Natural Gas \\
\hline Solensa SA DE CV & Natural Gas Liquefaction \& Liquefier \\
\hline
\end{tabular}




\section{Cooperative Research and Development Agreements}

INL has a very successful Cooperative Research and Development Agreement (CRADA) program. During the past five years, INL has signed 103 CRADAs representing more than $\$ 164$ million of research work. Ten new CRADAs were signed during FY 2009, while 26 modifications to existing CRADAs were negotiated. The total CRADA value during the year was more than $\$ 22$ million, including about $\$ 8$ million of fundsin, $\$ 9$ million of in-kind contributions from partners, and slightly more than $\$ 5$ million in government contributions.

A CRADA may be as short as a period of months or may extend several years depending on the objectives of the collaboration. The number of transactions and the corresponding resource commitments vary considerably from year to year based on the technologies available at INL, the readiness of participants to invest in collaborations, and INL's ability to identify the right partners and negotiate satisfactory business relationships.

\section{OriginOil inks CRADA on algae research}

In Feb. 2009, OriginOil, Inc., the developer of a breakthrough technology to transform algae, signed a cooperative research agreement with INL to begin a multi-phase research program. The agreement focuses on validation and commercial scaling of the company's technology in the production of algae-based fuels by using the state-of-the-art equipment, capabilities, scientists and engineers of the INL. The initial phase focused on the collaborative development of an energy balance model for photobioreactor-based algae systems. OriginOil expects to use this model

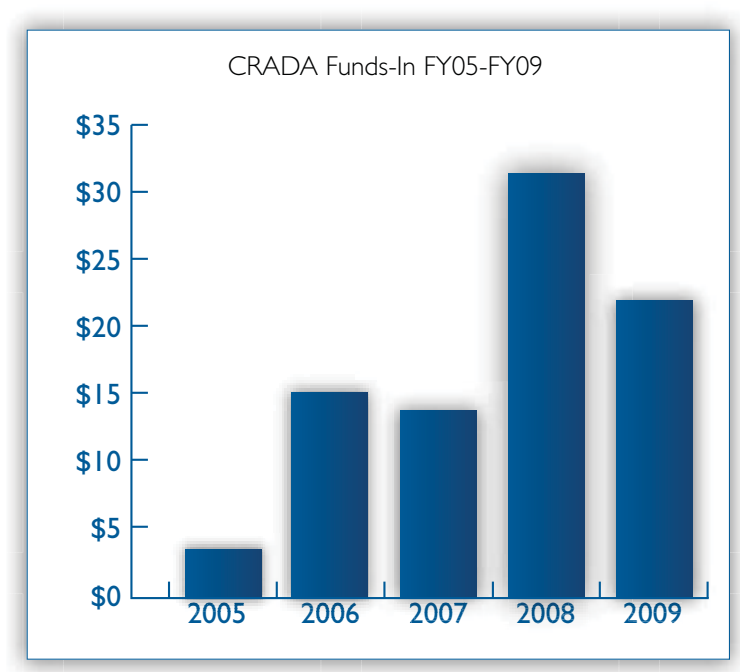

in the optimization of its algae-to-oil technology. Subsequent phases will center on validation of the OriginOil processes and piloting specific commercial applications.

INL advisory scientist Thomas H. Ulrich in INL's Biofuels and Renewable Energy department said, "INL has been tasked with the key National Security mandate of developing advanced renewable energy technology. Our primary challenge is cost-effective and scalable industrial processes and our partnership with OriginOil will help us find

A list of the remaining CRADAs is below, followed by a short summary of selected agreements.

\begin{tabular}{|c|c|}
\hline CRADA Partner & Technology \\
\hline Pebble Bed Modular Reactor (Pty) Ltd, South Africa & PBMRTRISCO Coated particles in AGR-2 Experiment \\
\hline Rosemount Inc. & Rosemount-INL System Assessments \\
\hline Rohm and Haas Company & $\begin{array}{l}\text { Plasma Carbothermic Reduction for Boron-Based Chemical } \\
\text { Hydride Production }\end{array}$ \\
\hline Electric Power Research Institute (EPRI) & $\begin{array}{l}\text { Baseline Fracture Toughness and SCC Testing of Alloys X750 } \\
\text { and XM- } 19\end{array}$ \\
\hline OriginOil, Inc. & Algae-to-Oil Conversion Scaling Investigations \\
\hline Commissariat a l'Energie Atomique & $\begin{array}{l}\text { Tri-structural Isotropic (TRISCO) Compacts in } \\
\text { AGR-2 Experiment }\end{array}$ \\
\hline Itron, Inc. & Itron Open Way Security Assessment \\
\hline Itron, Inc. & Itron Open Way Security Assessment \\
\hline Lindsey Manufacturing & $\begin{array}{l}\text { Modification of Transmission Line Security Monitor Sensor } \\
\text { Platform }\end{array}$ \\
\hline Siemens Corporate Research, Inc. & DOE-NETL Cyber Security Project (SCADA) \\
\hline IGE Energy Services, Limited & IGE Energy Services, Limited Assessments \\
\hline
\end{tabular}


solutions to this challenge in the promising area of algae-to-oil technology. Partnerships with innovators like OriginOil will accelerate our pursuit of national energy independence initiatives."

OriginOil's chief technology officer Vikram M. Pattarkine said, "Because algae represents such promise, we have been presented with numerous opportunities for partnerships in the public and private sector in the US and abroad. We decided to begin with INL because it would be very productive across all of our initiatives."

Based in Los Angeles, OriginOil, Inc. is developing technologies to transform algae into a true competitor to petroleum. Much of the world's oil and gas is made up of ancient algae deposits.

\section{Commissariat a l'Energie Atomique (CEA) agrees to fuel} research, support

In Mar. 2009, CEA and INL signed a cooperative agreement to conduct research as part of the Advance Gas Reactor-2 campaign with the goal of demonstrating and qualifying very high temperature reactor fuel. The joint research effort includes irradiating six capsules of fuel bound in cylindrical graphitic compacts, provided by CEA. INL will receive the fuel compact shipment and irradiate six experimental fuel compacts, providing reports on the irradiation conditions and in-pile performance to CEA.

The agreement includes the supply, characterization and shipment of CEA fuel compacts to INL and the design, assembly, irradiation of one AGR-2 fuel capsule containing six fuel compacts provided by CEA. Post irradiation examination of the six irradiate compact is not covered by this agreement. The period of the agreement extends beyond two years.

Itron Open Way Security Assessment. Itron, Inc. signed two CRADAs for INL to test and evaluate the susceptibilities and the value of protection strategies to enhance Itron's Open Way system robustness and security.

Modification of Transmission Line Security Monitor Sensor Platform. Lindsey Manufacturing signed a CRADA for INL to modify a transmission line monitor to incorporate two new ultrasonic sensors to determine the distance from the monitor to a conductor suspended below in the air or vegetation growing up towards the platform from the ground.

Plasma Carbothermic Reduction for Boron-Based Chemical Hydride Production. Rohm and Haas Company signed a CRADA for INL to assess the feasibility of developing a one-step, low cost carbothermal process for sodium borohydride production leading to cost effective production of boron-based chemical hydrides.

Baseline Fracture Toughness and SCC Testing of Alloys X750 and XM-19. Electric Power Research Institute (EPRI) signed a CRADA to build and validate a specific INL capability for characterizing metallic alloys used in Light Water Reactor environments.

IGE Energy Services, Limited Assessments. IGE Energy Services, Limited signed a CRADA to identify and develop mitigation solutions for General Electric ENMAC system vulnerabilities in the wake of advancing technologies.

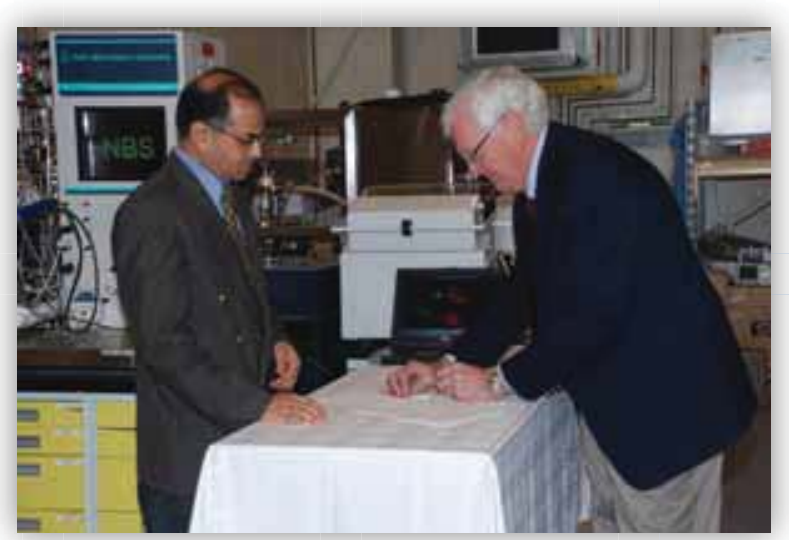

Vikram M. Pattarkine, OriginOil's chief technology officer, left, watches as David Anderson, INL Commercialization Manager, signs the cooperative and research development agreement on Feb. 17, 2009.

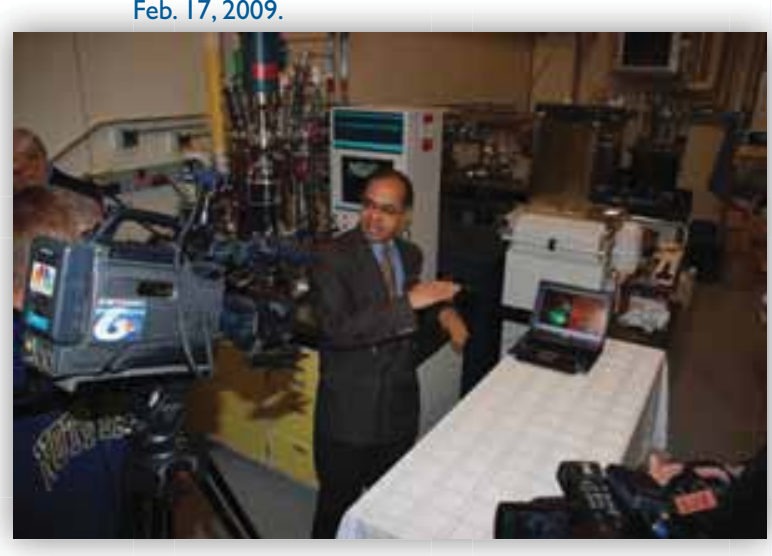

Vikram M. Pattarkine, OriginOil's chief technology officer, announces a cooperative research and development agreement with INL at a news conference on Feb. 17, 2009.

DOE-NETL Cyber Security Project (SCADA). Siemens Corporate Research, Inc. signed a CRADA for INL to determine the vulnerabilities, susceptibilities and to evaluate deployed system improvements for a Siemens Integrated Security System for the purpose of enhancing industry control system robustness.

PBMR TRISCO Coated particles in AGR-2 Experiment. Pebble Bed Modular Reactor (Pty) Ltd, South Africa signed a CRADA for fabrication, characterization and shipment of PBMR particles, and design, assembly and irradiation of the capsule containing the PBMR fuel in the AGR-2 experiment.

Rosemount-INL System Assessments. Rosemount, Inc. has signed a CRADA to have INL assess its wireless SmartPack system, a wireless sensor network management system to include pres-assessment, preparation and training, assessment and reporting. 


\section{Work For Others}

INL's Work for Others program has had an extremely productive five year period conducting work for customers outside of the Department of Energy. The WFO program has agreed to 267 projects that represent more than $\$ 1.6$ billion of work during that time.

FY 2009 was a very productive year for the WFO program with DOE Idaho approving 48 new projects worth a value of slightly more than $\$ 171$ million.

Also during the year WFO continued working to improve capabilities to process work requests. In 2007, the WFO office started using a new "Technical Services Agreement" (TSA). This agreement was designed to streamline processing for agreements representing low dollar amounts and low risk WFO projects.

In FY 2009, the WFO office worked to leverage information technologies to test, validate and implement a process using computerized automation.

WFO Manager, Al Hoiland, said, "BEA recognizes that becoming the preeminent nuclear energy laboratory and accomplishing DOE's scientific objectives is our primary mission. However, in order to accomplish this mission the INL needs to establish a strong relationship with the United States' commercial nuclear industry and take a central role in revitalizing nuclear science, engineering, education and training. Designing new tools like the Work For Other Processing System (WPS) enables the INL to engage industrial partners with the speed and efficiency that industry expects and will enhance BEA's ability to develop and maintain the Lab's core capabilities. ”

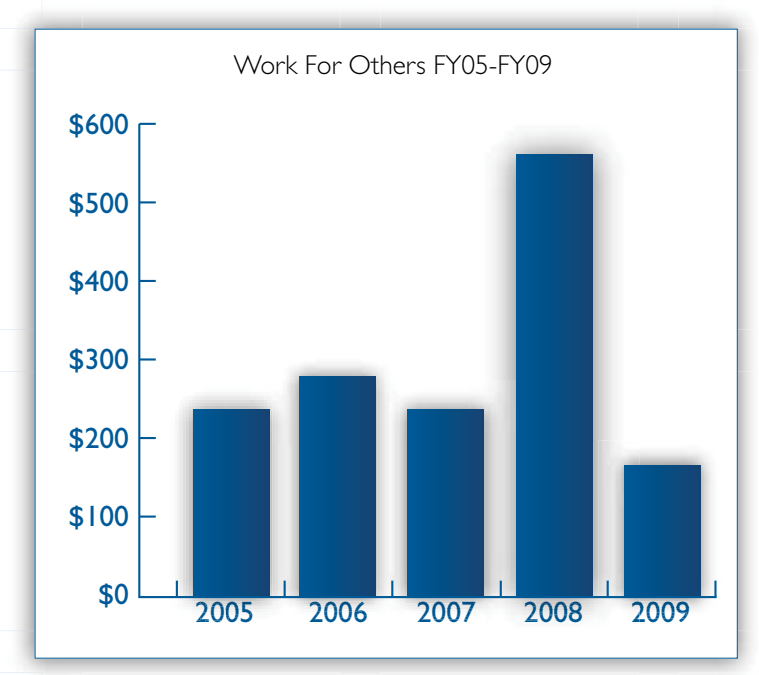

Some of INL's more significant WFO projects include:

Federal Wind Projects - Umbrella Agreement. Managed by Gary Seifert, this WFO project is an "umbrella type WFO" that allows BEA to support multiple federal agencies for conducting renewable energy systems integration, resource assessment, and highly reliable energy systems projects.

Battelle Fast Pyrolisis. Dr. Richard Hess and his biomass team will develop a feedstock assembly process for fast pyrolysis of indigenous cellulosic biomass (focus on oil palm empty fruit bunches, EFBs) to produce a stable (sweet crude quality) bio-oil for a petroleum substitute. In this project, INL will develop a feedstock assembly process for fast pyrolysis processing and subsequent bio-oil upgrading. Feedstock assembly unit operations, including collection, storage, preprocessing, and transportation, will be considered with options and interfaces identified and evaluated in order to optimize quality and reduce feedstock costs.

Electric Grid Reliability.For the Assistant Secretary of Defense for Homeland Defense, Scott McBride is managing a project that will enhance electrical power grid modeling capabilities used for the analysis of Defense Critical Infrastructures. Mcbride will investigate other power grid models and utilities within CIPRsim. The project also will integrate those grid models with systems in larger geographic areas for analysis and work to overcome the current limitation of CIPRsim to receive and display current power grid data.

\section{A list of new WFO and TSA projects approved and funded during 2009 are provided below.}

Swedish Emergency Management Agency (SEMA) Training and Test Bed Interchange. The Swedish Emergency Management Agency (SEMA) is seeking INL assistance to provide basic technical training in control system cyber security. The work will apply the lessons learned from establishing partnerships among public and private sectors to identify and mitigate cyber security vulnerabilities in control systems. Members from Swedish agencies will attend training and participate in a discussion of lessons learned to assist SEMA in establishing their laboratory for infrastructure analysis.

Idaho National Laboratory's Survivability Program. In support of the Office of Naval Research, the INL Survivability Program conducted a focused research project to enhance selected personnel, vehicle and critical infrastructure armor technologies. This multitask project included advanced ballistic, blast and transparent armor materials development and testing at the INL National Security Test Range. In addition the project acquired equipment capabilities to support future research and development on survivability systems, especially focused on the Explosively Formed Projectiles (EFP) and blast threats to our nation's military personnel. 
DARPA National Cyber Range. In 2009, INL provided unique expertise in working with Johns Hopkins University Applied Physics Laboratory (JHU/APL) to support development of the Concept of Operations for the National Cyber Range. This joint effort is part of DARPA's contribution to the federal Comprehensive National Cyber Initiative (CNCI).

Disaster Response: Communications and Other Infrastructure Restoration Program. For the Assistant Secretary of Defense Homeland Defense \& Americas' Security Affairs (OASD/HD\&ASA); Defense Critical Infrastructure Program (DCIP). The INL is developing a simulation and modeling program to enhance existing electrical grid and network modeling capabilities demonstrated on a GIS platform. This will aid in the analyses and understanding of Defense Critical Infrastructure (DCI) asset vulnerability risks attributed to infrastructure interdependences. Studying the behavior of the interdependencies of infrastructures, when under direct attack or under duress due to natural disasters or adversarial attack (either cyber or kinetic) will greatly aid DCIP in accomplishing its objective.

Environmental Security Technology Certification Program (ESTCP) MNA Probes. The primary objective of this demonstration is to develop the relationship between enzyme activity probes (EAP) and contaminant degradation rates. Microcosm studies will be performed on samples collected from the TCE-contaminated aquifer. It will combine: (a) EAP specific for aerobic oxygenase enzymes, (b) molecular techniques such as polymerase chain reaction (PCR) and fluorescent in situ hybridization (FISH) to provide evidence in support of EAP, and (c) contaminant transformation measurements to determine the rates of TCE cometabolism. This demonstration will provide a comprehensive assessment of active degradation mechanisms in groundwater and soil, as well as an estimate of the rate of contaminant degradation.

Thermal Viruses for Yellowstone. This work supports a joint project between INL and Montana State University funded by the National Science Foundation to study thermal viruses in Yellowstone. The INL will direct and guide DNA sequencing and bioinformatic analyses relating to this study.

\section{Carbon Dioxide Mineralization Potential of Host Rocks in Deep Saline Aquifers.}

The sponsor has asked the INL to apply its expertise in the field of carbon sequestration to develop the data that is needed to run predictive models. INL is involved in DOE's carbon sequestration program as a member of the Big Sky Carbon Sequestration Partnership and has been performing research and development in the area of geologic sequestration for a number of years. Sequestering CO2 has the potential to significantly reduce green house gas emissions to the atmosphere.
Adelos - Fiber Optic Acoustic Perimeter Detection. For the U.S. Navy, a team from INL will test an imperceptible (buried) fiber optic acoustic sensor system useful for perimeter monitoring/protection of various critical infrastructures (nuclear facilities, processing plants, electrical facilities, etc.). INL will test the system at the National Security Test Range using already installed sensor arrays and gather data for a variety of acoustic stimuli for analysis and signature library development.

GSES RELAP5-RT Technical Assistance. The Central Research Institute of Electric Power Industry (CRIEPI), which represents the Japanese Nuclear Power Utilities (JU), has requested access to the INL's fission product gas data that resulted from the Dry Cask Storage Pad sampling program. This data will support a safety case to replace the visual inspection requirement with a fuel integrity criterion based on fission product gas concentration data. Of particular interest is the information from the Castor V/21 because it may represent a best-case baseline.

Modeling Proppant-Shale Interaction in Hydraulic Fractures Using Particle-Based Discrete Element Model Coupled with Fluid Flow and Heat Conduction. A large oil Exploration and Production Company has requested the INL to investigate and quantify the behavior of proppants within high temperature plastic fractures at the interface between proppants and the fracture walls, and assess this impact on overall hydraulic fracture performance (i.e. changes on fracture permeability and conductivity). A particle-based discrete element model (DEM) coupled with fluid flow and heat conduction, developed at the INL will be modified for this analysis.. The resulting fracture deformation (compaction) and the penetration of the proppant particles into the fracture walls will be calculated and analyzed. 


\section{Remaining WFO projects are listed below.}

\section{WFO Sponsor}

Daniel B. Stephens \& Associates

Battelle Memorial Institute

Battelle Memorial Institute

NASA Glenn Research Center

Lynntech, Inc.
Technology

Requested assistance with the installation, operation and interpretation of data from Advanced Tensiometers (INL Patented Technology).

Provide technical expertise in the general field of computational and experimental nuclear science.

INL is helping BMI define R\&D programs needed to establish a Renewable Energy Laboratory in Malaysia with an initial focus on the conversion of biomass to fuels and chemicals. Space Nuclear Systems Support to NASA.

The INL is consulting with the Sponsor on the use of non-thermal plasma technology in converting heavy hydrocarbons into value added distillates.

Defense R\&D Canada

Air Force Research Laboratory

Babcock \& Wilcox Company

Environmental Protection Agency

AMEC Geomatrix Inc. Portable Isotopic Neutron Spectroscopy (PINS) Training. Use of facility to conduct test flights.

Provided technical assistance in support of the sponsor's medical isotope production system.

Sponsor requested INL's assistance to install an advanced monitoring system of geophysical, hydrological and geochemical monitoring components at the Barite Hill Lake site.

Sponsor has requested INL's participation on an expert technical review panel for the Hanford Deep Vadose Zone Treatability Test Project.

Strategic Environmental Research \& Development Program (SERDP)

United States Air Force

GSE Power Systems, Inc.

Defense Threat Reduction Agency (DTRA)

Babcock \& Wilcox Corporation

Analysis \& Measurement Systems (AMS)

Department of Homeland Security Infrastructure \& Geophysical Division
Project consists of numerical modeling, and the delivery of a numerical model of well flow dynamics.

Disassemble the Remote Standoff Explosive Detection System (R/SEDS) and return it to the INL.

Provide RELAP-RT (software) technical support.

Sponsor requests INL assistance to integrate its patented Robot Intelligence Kernel (RIK) and its behavioral capabilities onto its robotic platform.

Develop a novel liquid phosphazene sorbent for $\mathrm{CO} 2$ capture. On-line monitoring technology for aging management and life extension of the Advanced Test Reactor at INL. Transformers used to energize substations during outages caused by equipment failure, weather, earthquakes, etc.
Assist in the development and testing of Extreme High Voltage 


\section{Technical Assistance Program}

The INL Technical Assistance Program (TAP) was refocused in FY 2009 to support business retention and expansion activities and job creation projects, specific to tech-based economic development. INL's economic development partners requesting technical assistance can receive up to 40 hours.

During the past five years, INL's TAP supported 113 projects with more than 5,000 hours of technical expertise. Of these projects, the majority were focused on community requests in rural areas that were designed to lead to job creation in the future.

In FY 2009, INL completed 21 technical assistance projects with Idaho Falls Downtown Development Corp, Grand Teton Brewing Company, University of Idaho Glass Blower, BT National Forest, Three Creek Project, Teton County Landfill, District 91 Process Improvements, NonProfit Testing, ESTEC Programs, Salvation Army, Smart Grid - Ammon, Glacier National Park, Arco Courtroom, Albatross UV, Good Earth Bio-Solutions, the Idaho Department of Water Resources and Manning Applied Technology. In some cases more than one project was involved.

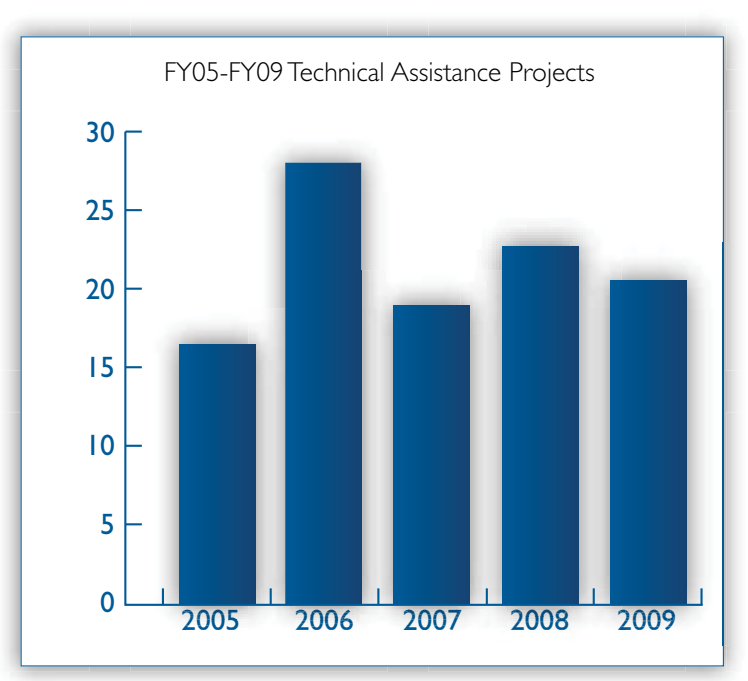

\section{Examples of Technical Assistance Program}

Good Earth Bio Solutions, winner of the Perkins Coie People's Choice Award at TechLaunch 6.0 in May of 2009, received technical assistance from the Lab to produce samples to be used for demonstration purposes for potential investors in a start-up business. In addition, work continues on formalizing a license agreement with the company on INL's Blue Mussel Adhesive invention.

Glass work was provided for the University of Idaho, Idaho State University, BYU-Idaho and Atlas Mechanical. For the University of Idaho Glass Blower project, a prototype was developed, creating a professionally fused vessel. This allowed the individuals to process the Microwave Lamp and present it to their prospective customer. For Idaho State University, INL created 20 heavy wall quartz test tubes, 8 custom manifold tees, 24 extraction tubes and 12 manifold jumpers. For BYU-Idaho, INL created 34 "long 26mm OD Quartz reactor with ground joints. To accommodate draining piping for the Atlas Mechanical project, INL drilled a 2" diameter hole in the bottom of a 14" diameter glass condenser bowl, which was a unique product manufactured in Finland.

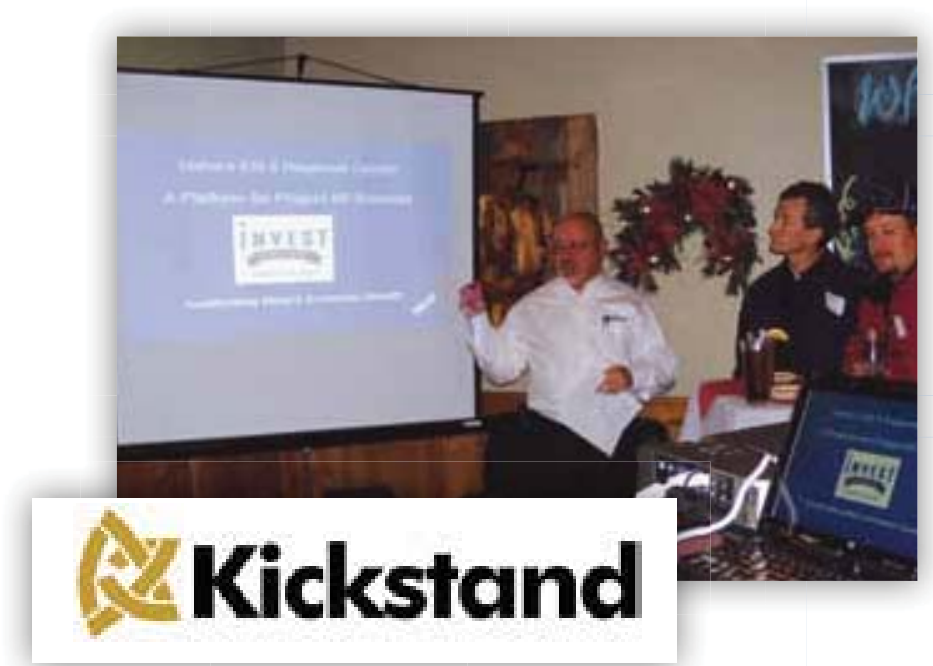

Nancy Bergmann, INL's economic development and technical assistant program manager, said, "During the past year, our work with regional partners on business retention and expansion have paid significant dividends retaining more than 3,000 jobs and creating about 600 more." Here, during an INLsponsored business networking meeting called Kickstand, Idaho TechConnect CEO and President Rick Ritter outlined the new Invest Idaho Regional Center, part of the Employment Base 5 program sponsored by the U.S. Citizenship and Immigration Service. 


\section{INL Economic Development 2009 Program Highlights}

\section{Overview}

As a key high-technology employer in the region, Idaho National Laboratory is a valuable technology-based economic development engine for Idaho and important to commercializing technologies in America.

INL's economic development organization works through existing local, regional, state and national groups to establish a strong climate for technology-based economic development. These efforts primarily focus on encouraging potential enterprises to develop high technology businesses with very skilled workers. Working with partners, available funding is leveraged to match monies to start technology-based projects.

During the current challenging economic period, regional economic development organizations, including INL, have maintained strong relationships that have yielded some impressive results. This successful regional collaboration brought a major AREVA project to eastern Idaho during FY 2008. Into FY 2009, these economic development partners continued recruiting into the region Hoku Materials, Petersen Incorporated, Whisper Creek Log Builders, Hamton Custom Builders, and Nordic Windpower. Business retention and expansion has been a key focus around the state. In eastern Idaho these efforts centered on TetriDyn Solutions, Positron, Heinz Frozen Foods, SME, Eaton, Frazier, Convergys, Teleperformance, Portneuf Medical Center, Premier Technology, Virginia Transformer, ON Semiconductor, Farmers Insurance, Simplot-Don Plant, and Monsanto. These efforts in eastern Idaho have resulted in the retention of more than 3,000 direct jobs and the creation of approximately 600 jobs.

\section{Leveraging Economic Development Partnerships}

INL Economic Development works with and sponsors several partners who are key to successfully pursuing these efforts, including:

- Idaho TechConnect - Idaho's first and only private-public non-profit focused on development, transfer and commercialization of technology. Additional information can be found in the following pages.

- Kickstand Idaho - An Idaho entrepreneurial networking organization that began in 2002 to sponsor and participate in entrepreneurial and business networking activities (such as regional Kickstand events and the annual IdaVation conference).

- Science on Tap and Science Café - Events in northern Idaho that focus on the commercialization and transfer of ideas and technologies from labs to the market. This includes sponsorship as well as providing speakers for monthly meetings.

- Idaho Economic Development Association - A state trade association of professionals and affiliated entities promoting economic development through conferences and workshops to identify regional technology-based economic development opportunities.

- Idaho Rural Partnership - A state-sponsored, public-private group working to improve economic and social conditions in rural Idaho.
With these partners and many others, INL sponsors programs and activities to promote economic development and the creation of a high technology work force for the future. Some of those activities include:

- Idaho TechLaunch - An annual event sponsored with a dozen partners that promotes high technology enterprises through a competition for prize money and notoriety. Nearly 40 companies have competed for nearly $\$ 40$ million of early-stage research funding during the past five years. As of FY 2009, 32 of those companies remain in business.

- Idaho Ideas to Market - I2M provides Idaho university students with hands-on opportunities to determine market feasibility for ideas and technologies.

- Idaho Internship and Entrepreneurial Program - Hosting an MBA internship program that leverages MBA student learning opportunities to aid startups.

- Contributing directly to State efforts to advance technology-based economic development planning.

- Sponsoring or supporting seed/venture capital activities, Small Business Innovation Research (SBIR) and Small Business Tech Transfer Program (STTR) workshops and conferences.

- Providing hands-on educational opportunities for Idaho university students through market feasibility activities on INL developed ideas and technologies.

INL's partnership with Idaho TechConnect has produced some amazing results during the past three years. Since the program's inception, 1,177 companies have been assisted. Of this total, $65 \%$ are existing businesses and 35\% represent new/start-up business activities. As of July 31, 2009, this has resulted in 862 jobs (and represents reporting from $37 \%$ of ongoing clients). Total annual wages as of July 31, 2009 are almost $\$ 52$ million. These businesses have contributed more than $\$ 3.5$ million in Idaho income taxes paid. Altogether, these efforts represent a total investment since 2006 of $\$ 39,800,000$. Of this, $\$ 14.4$ million represents actual investment dollars and $\$ 25.4$ million represents research and development funds.

During FY 2009, Idaho TechConnect provided assistance or referral to 393 companies and individuals. Of this total, 275 (71\%) were new clients, while 118 (29\%) were ongoing from FY 2008. Of the 275 new clients, 151 (55\%) became ongoing clients and 124 (45\%) were referred to other services or organizations. These numbers demonstrate significant success and some tremendous growth in providing development services delivered within the regional economy. 


\section{Coordinating Federal Assistance for Companies}

During FY 2009, 134 companies/individuals received assistance related to obtaining Federal Financial Assistance. This assistance includes, but is not limited to, SBIR/STTR, Broad Agency Announcements (BAA), federal and large company procurement, Request for Information (RFI), Funding Opportunity Availability (FOA) and federal appropriations process and contacts.

Of the 134 companies/individuals, 33 were referred to the Idaho Department of Commerce (IDOC) Grant Proposal Incentive (GPI) program, which meets the contract goal outlined between IDOC and Idaho TechConnect. In addition, seven regional SBIR workshops were attended by more than 80 people and a statewide conference had attendance of nearly 100 people.

Two companies have received Phase I awards during the year and both have submitted Phase II proposals. Five companies who received assistance in FY 2008 have been awarded Phase I contracts that totaled just under $\$ 500,000$. Two of these companies have successfully completed Phase I contracts and applied for Phase II funding. If these applications are awarded more than $\$ 4$ million would be received by these companies.

\section{Economic Development Education and Training}

Idaho Ideas To Market (I2M) Program. Idaho TechConnect and INL developed the Idaho Ideas to Market (I2M) program to provide Idaho college and university students with a hands-on approach in determining the market feasibility of an idea developed at the INL. Each team works with faculty members to conduct market assessments and analysis on the same idea as selected by the INL. Efforts should address whether the idea may have the potential to be a start-up company and evaluate the opportunity, addressing market barriers and identifying ways in which the idea may be used to start and grow a viable business. The pilot program in 2008 began with 1 graduate student team at Boise State University. A final report was delivered in May of 2009 at TechLaunch 6.0 and to INL. INL is reviewing the report's recommendations for next steps. Through the Battelle Sharepoint, several Battelle partners are considering adopting the I2M Program. Battelle UK has adopted the program.

"So what? who cares? why you?" Training and Workshops. In October of 2008, Idaho TechConnect entered into a partnership agreement with Wendy Kennedy to provide workshops, materials, website access and coaching to the Idaho National Laboratory and the colleges and universities within Idaho. An agreement was signed in February of 2009 and the first workshops and coaching sessions were delivered in March 2009. During FY 2009 forty researchers and technology deployment individuals have been trained.

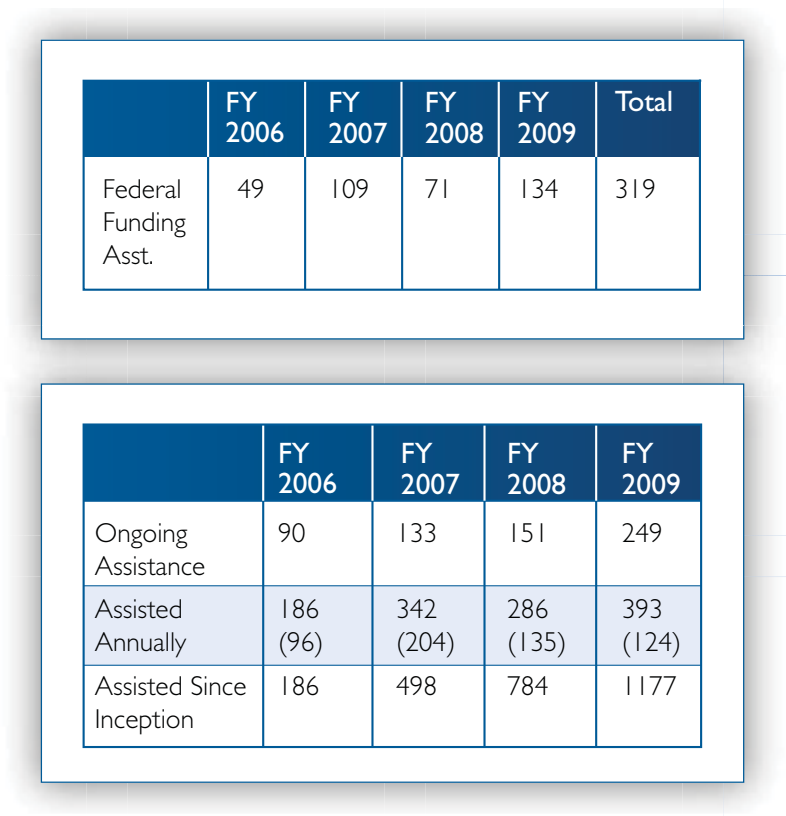




\section{Other Successes}

\section{INL researchers win three 2009 R\&D 100 awards}

INL experienced an exceptional year in the 2009 R\&D 100 award competition with a 75 percent selection rate. Three of four nominated technologies from were selected as winners for 2009.

One of the technologies was a nanotechnology breakthrough that delivers the promise of providing researchers and industrial companies abundant, affordable nanoparticles from a variety of materials.

Bob Fox's Precision Nanoparticles process uses supercritical carbon dioxide to produce prescribed sized high quality, uniform that range from smaller than $1 \mathrm{NM}$ to $100 \mathrm{NM}$. Using temperature and pressure variances well within current commercial capabilities, Precision Nanoparticles can deliver specified sized copper indium disulfide nanoparticles to harvest photon energy across the most intense segments of the solar spectrum. This may offer a major advance in producing new, more efficient solar materials to heat and power homes, businesses and the nation. It is licensed to Precision Nanoparticles of Seattle, Wash.

A second winning technology is a joint effort with U.S. EPA Cincinnati scientists that developed a Water Sample Concentrator to reduce a test sample size from a suspected contaminated source from 100 liters (more than 200 pounds) to a concentrated 250 milliliter sample (about one-half of a pound). This permits easier transport of a sample to a qualified laboratory and faster sample gathering, while preserving suspected pathogens. It also safeguards the individuals gathering samples with a fully-contained and isolated sample system. This is a major contribution to ensuring proper water quality and was selected as an Editor's Choice technology at the awards ceremony in Orlando, Florida in November 2009. It has been licensed by Teledyne Isco, Inc. of Lincoln, Nebr.

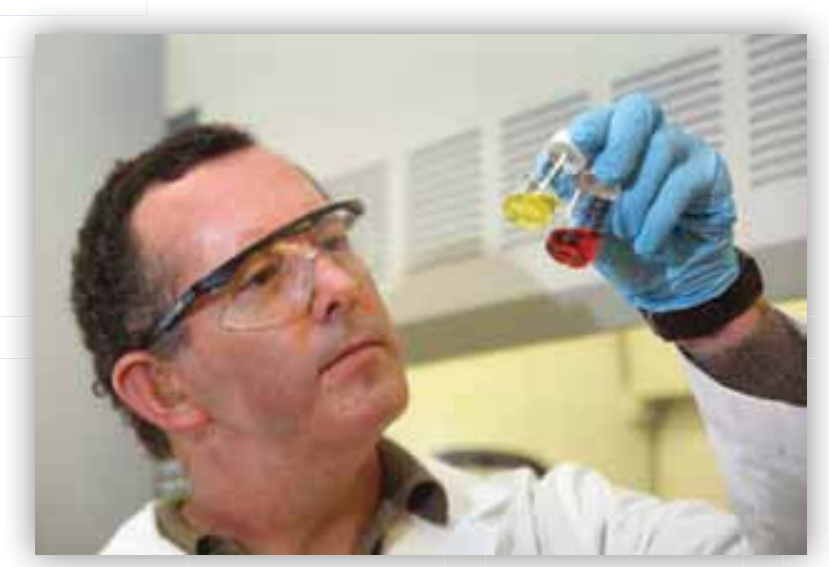

INL researcher Dr. Robert Fox inspects nanoparticles produced using Precision Nanoparticles technology, which offers an affordable method of producing uniform nanoparticles in a wide range of sizes (less than I to I00 nanometers).
The third winner is a technology that uses an INL breakthrough in secure transactions. Called RFinity, this technology offers a hardware/software solution that enables secure transaction computations and transmissions to and from other RFinity-enabled devices. RFinity can transform current cell phones that use a microSD card into safe, secure financial and transaction devices. RFinity 's plug-n-play hardware contains a radio frequency identification transponder, which uses two-way near-field communications among cell phone, RFID product labels and other enabled systems. Using U.S. National Security Agency Suite B encryption standards, RFinity uses a one-time code infrastructure for contactless, single-click transactions for business, identification, sensitive record retrieval and much more. It is licensed to RFinity, Inc.

\section{INL Technologies Recognized at Annual Idaho Innovation Awards}

INL's Robert Fox and Idaho State University chemists Rene' Rodriguez and Joshua Pak won honors as the Early Stage Innovation of the Year during the fourth annual Idaho Innovation Awards banquet Thursday, Sep. 24 in Boise. Presented by Stoel Rives LLP and Kickstand, the special awards banquet was attended by Governor C.L. "Butch" Otter and more than 200 representatives from Idaho's business, technology, academic and government communities. A R\&D 100 award winner in July of 2009, Precision Nanoparticles is a revolutionary and efficient nanoparticle production technology that delivers uniform, prescribed nanoparticles (1-100 nanometers) using supercritical fluids.

Also, INL's Water Sample Concentrator technology, developed by INL's Mike Carpenter, Lyle Roybal, and Paul Tremblay with scientists from EPA's Cincinnati laboratory, was a finalist in this annual competition.

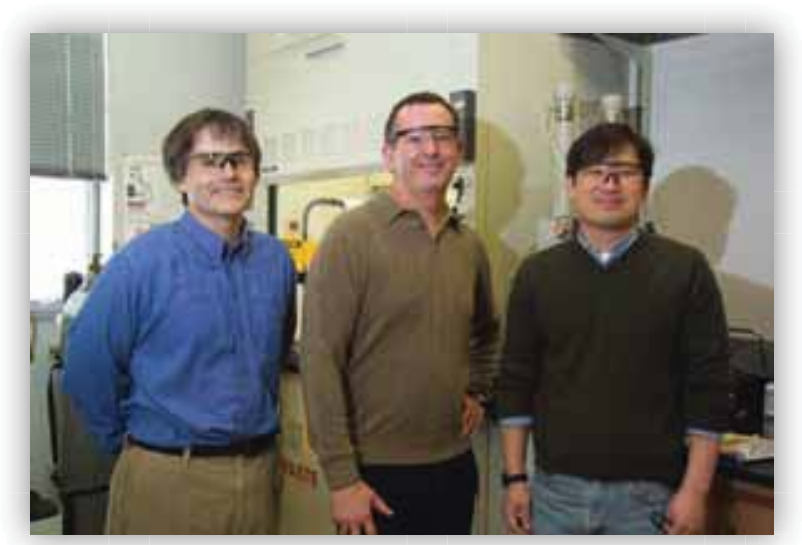

The Precision Nanoparticles research team includes Idaho State University's Dr. Rene' G. Rodriguez (left), INL's Dr. Robert V. Fox (center), and ISU's Dr. Joshua J. Pak (right). Precision Nanoparticles won a 2009 R\&D 100 award. 


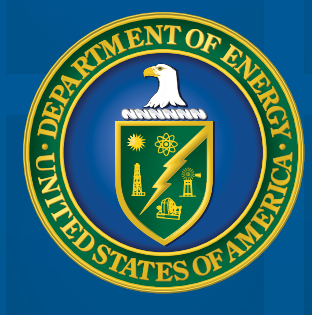

INL is one of the U.S. Department of Energy's

Multiprogram national laboratories and is managed by

Battelle Energy Alliance, LLC. 